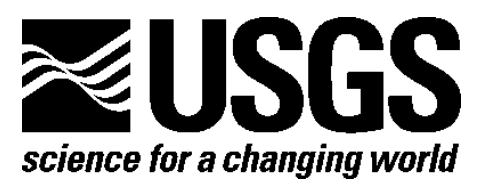

\title{
Earthquake Catalog for Estimation of Maximum Earthquake Magnitude, Central and Eastern United States: Part B, Historical Earthquakes
}

By Russell L. Wheeler

Open-File Report 2014-1025-B

U.S. Department of the Interior U.S. Geological Survey 


\section{U.S. Department of the Interior \\ SALLY JEWELL, Secretary}

\section{U.S. Geological Survey \\ Suzette M. Kimball, Acting Director}

U.S. Geological Survey, Reston, Virginia 2014

For product and ordering information:

World Wide Web: http://www.usgs.gov/pubprod

Telephone: 1-888-ASK-USGS

For more information on the USGS - the Federal source for science about the Earth,

its natural and living resources, natural hazards, and the environment:

World Wide Web: http://www.usgs.gov

Telephone: 1-888-ASK-USGS

Suggested citation:

Wheeler, R.L., 2014, Earthquake catalog for estimation of maximum earthquake magnitude, Central and Eastern United States_Part B, Historical Earthquakes: U.S. Geological Survey Open-File Report 20141025-B, 30 p., http://dx.doi.org/10.3133/ofr20141025B.

ISSN 2331-1258 (online)

Any use of trade, product, or firm names is for descriptive purposes only and does not imply endorsement by the U.S. Government.

Although this report is in the public domain, permission must be secured from the individual copyright owners to reproduce any copyrighted material contained within this report. 


\section{Contents}

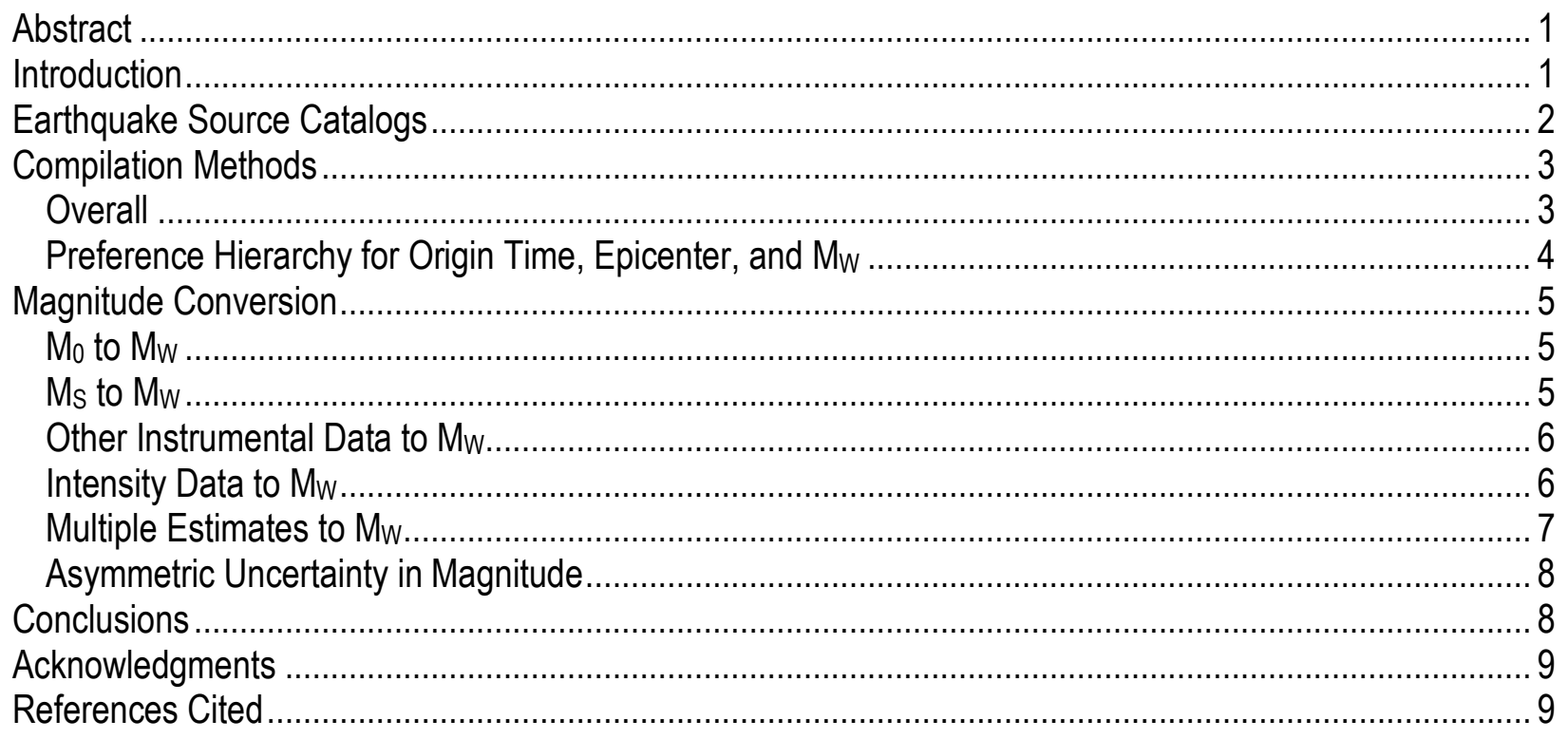

\section{Figure}

Figure 1. Map showing fifteen global stable continental regions ...................................................... 2

\section{Tables}

Table 1. Global catalogs used to compile SCR (stable continental region) earthquakes...................... 15

Table 2. Foreshocks and aftershocks .................................................................................. 17

Table 3. Stable continental region earthquakes now recognized as having occurred in active

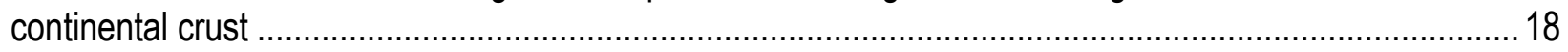

Table 4. Events not verified as earthquakes......................................................................... 20

Table 5. Preference hierarchy for choice of the best value from among those in two or more

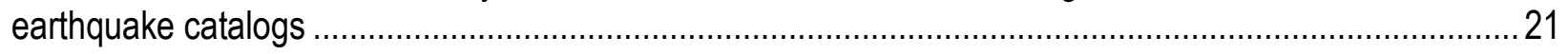

Table 6. Earthquakes having two or more size estimates that were combined with the method of

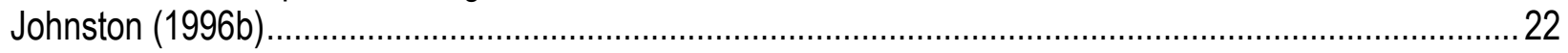

Table 7. Mw estimates not used ......................................................................................... 29

Table 8. Global Catalog of Historical Earthquakes for Estimation of Mmax in Central and Eastern

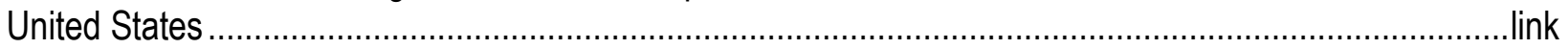




\title{
Earthquake Catalog for Estimation of Maximum Earthquake Magnitude, Central and Eastern United States: Part B, Historical Earthquakes
}

\author{
By Russell L. Wheeler
}

\begin{abstract}
Computation of probabilistic earthquake hazard requires an estimate of Mmax: the moment magnitude of the largest earthquake that is thought to be possible within a specified geographic region. The region specified in this report is the Central and Eastern United States and adjacent Canada. Parts A and $\mathrm{B}$ of this report describe the construction of a global catalog of moderate to large earthquakes that occurred worldwide in tectonic analogs of the Central and Eastern United States. Examination of histograms of the magnitudes of these earthquakes allows estimation of Central and Eastern United States Mmax. The catalog and Mmax estimates derived from it are used in the 2014 edition of the U.S. Geological Survey national seismic-hazard maps. Part A deals with prehistoric earthquakes, and this part deals with historical events.
\end{abstract}

\section{Introduction}

Computation of probabilistic seismic hazard requires a value of Mmax, which is an estimate of the moment magnitude $\left(\mathrm{M}_{\mathrm{W}}\right)$ of the largest earthquake that is thought to be possible within a specified geographic region (Wheeler, 2009a, b). In the sparsely seismically active Central and Eastern United States (CEUS) and adjacent Canada east of the Rocky Mountains, earthquakes large enough to be candidates for Mmax are rare. In most of the CEUS, the historical earthquake record is shorter than the time intervals between large earthquakes, so Mmax must be estimated indirectly from large earthquakes that have occurred in tectonically similar areas worldwide (Chinnery, 1979; Coppersmith, 1994; Coppersmith and others, 1987).

The CEUS is part of a stable continental region (SCR) (Johnston, 1994; Kanter, 1994) that is tectonically analogous to other SCRs identified in figure 1, all of which lack young tectonism (Kanter, 1994). Kanter defines this lack as the absence of orogeny, foreland deformation, or widespread anorogenic intrusion since the Early Cretaceous Epoch (since 100 million years ago [Ma]: Gradstein and others, 2004), and the absence of significant extension since the Paleogene Period (since $23 \mathrm{Ma}$ ). These criteria distinguish SCR crust from active continental regions (ACR), oceanic crust, and plate boundaries.

Part A of this Open-File Report (Wheeler, 2014) is a catalog of moderate to large prehistoric SCR earthquakes in North America, northern Europe, and Australia. Part B (this report) describes the construction of a companion global catalog of historical SCR earthquakes, hereafter identified as W13B. The combined catalogs support the estimation of Mmax in the CEUS as necessitated by the 2014 USGS National Seismic Hazard Maps (Petersen and others, 2014). The estimation methodology is beyond the scope of this report. 


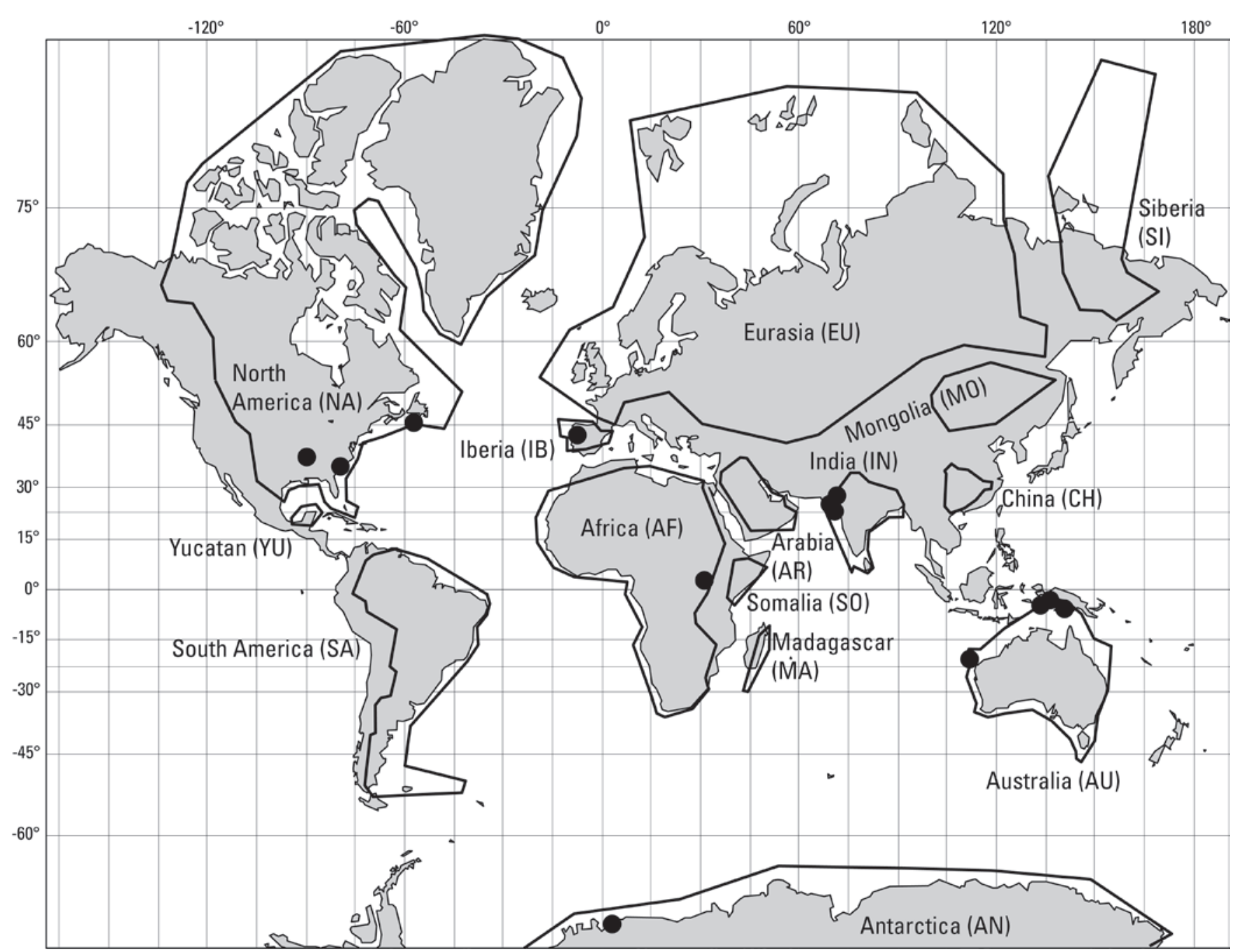

Figure 1. Fifteen global stable continental regions (SCRs), following Johnston and others (1994) and Wheeler (2011). The two-letter codes in parentheses identify individual SCRs and their earthquakes throughout the tables and text. The CH SCR is the South China Block of Wheeler (2011). It is part of the larger China SCR of Johnston and others (1994), most of which is now known to exhibit rifting younger than allowed by the definition of SCR (Johnston, 1994; Kanter, 1994). Black dots show epicenters of the 13 historical SCR earthquakes with moment magnitude Mw7.0 or larger.

\section{Earthquake Source Catalogs}

Five global earthquake catalogs span all known moderate to large historical earthquakes in SCRs; each catalog contains one record per earthquake. (See table 1 for characteristics of these catalogs and supplementary catalogs used.) For this report, all records of SCR earthquakes having at least one magnitude of any type that is 6.0 or greater were extracted from each of the five global catalogs.

Of the five catalogs, Johnston and others (1994; J94 hereafter) and Schulte and Mooney (2005; SM05) deal solely with SCR earthquakes. (An exception is that J94 also lists a handful of notable earthquakes outside SCRs that are of interest for discussions of Johnston [1994]). J94 lists data on numerous seismological properties and characteristics of the tectonic settings of all SCR earthquakes having any type of magnitude of at least 5.0, or Modified Mercalli Intensity of at least VII. For 
properties with more than one published estimate, J94 lists each and identifies one as preferred. Each data item is attributed to its source; most data items are drawn from primary sources. (As used in this report, primary sources contain information that has not been reported elsewhere, whereas secondary sources consist mostly of information that has been published or otherwise reported in one or more primary or secondary sources.) Although J94 is a secondary source, it forms the basis of this report's compilation, given J94's breadth and depth of search, thoroughness of analysis, and completeness of documentation. SM05 updates J94 through October 31, 2003.

The other three global catalogs are dominated by ACR, oceanic-crust, and plate-boundary earthquakes, but list SCR earthquakes as well. The oldest of the three catalogs is by Triep and Sykes (1997), who published a catalog of intracontinental earthquakes outside subduction zones (TS97 hereafter). Second, Engdahl and Villasenor (2002) published the Centennial catalog: a compilation of earthquakes that occurred from 1900 to 1999. Origin times, epicenters, and depths were computed with the Earth model AK135 and the EHB algorithm of Engdahl and others (1998). The catalog was updated with new earthquake data in 2002, 2005, 2007, and 2008. Each update includes revised earthquake origin times, epicenters, and depths computed with successively improved applications of AK135 and EHB. The 2008 update to the Centennial catalog was provided by A. Villasenor (Institute of Earth Sciences "Jaume Almera," CSIC, Barcelona, Spain; written communs. between February 28, 2008 and September 9, 2009; C08 hereafter). The most recent of the three catalogs is the Global Earthquake Model catalog of Storchak and others (2012; GEM hereafter).

J94, TS97, SM05, C08, and GEM incorporate numerous older global and regional catalogs, both primary and secondary sources. The older catalogs (see table 1) were only consulted as needed for additional information on specific earthquakes. In addition, four regional catalogs were used to supplement the earthquake record in areas that include parts or all of SCRs (see table 1). None of the regional catalogs contribute SCR earthquakes large enough to be included in W13B.

Large SCR earthquakes are infrequent worldwide; most of them predate the widespread use of $\mathrm{M}_{\mathrm{W}}$ over recent decades. Earthquakes that occurred before the advent of seismographic instruments around 1900 have magnitudes calculated from intensity reports. Magnitudes that predate $\mathrm{M}_{\mathrm{W}}$ are converted to $\mathrm{M}_{\mathrm{W}}$, typically with regression equations as described in a later section on "Magnitude Conversions."

The catalog presented here (W13B) is more appropriate for estimating CEUS Mmax than either of the two catalogs produced by the Seismic Source Characterization (SSC) report (Electric Power Research Institute and others, 2012; EPRI and others, 2012 hereafter). The first SSC catalog is a moment-magnitude catalog for the CEUS (chapter 3 of EPRI and others, 2012) and contains few earthquakes large enough to constrain Mmax and associated magnitude-conversion equations compared to the worldwide database of W13B. The second SSC catalog is a global catalog through 2008 of SCR earthquakes that have $\mathrm{M}_{\mathrm{W}}$ roughly 5.0 and larger (Appendix K of EPRI and others, 2012). The SSC global catalog was compiled from J94 (see definitions in table 1), SM05, and CMT (Global Centroid Moment-Tensor Project). In contrast, preparation of W13B involved all or parts of these three global catalogs and eight other global catalogs (see table 1).

\section{Compilation Methods}

\section{Overall}

To adequately characterize Mmax in the CEUS, computation of the USGS National Seismic Hazard Maps requires a catalog of SCR earthquakes that spans a wide enough range of $\mathrm{M}_{\mathrm{W}}$. Recent editions of the maps have taken Mmax as 7.0 or 7.5 in different parts of the CEUS (Frankel and others, 
2002; Petersen and others, 2008; Wheeler and Frankel, 2000), so this compilation targets all SCR earthquakes with $\mathrm{M}_{\mathrm{W}}$ at least 6.5. To achieve this, W13B includes all records from the first four of the five global catalogs of table 1 having any type of magnitude at least 6.0; this guarantees inclusion of earthquakes of $\mathrm{M}_{\mathrm{W}}$ at least 6.5 after conversion from other magnitude scales, such as surface wave magnitude $\mathrm{M}_{\mathrm{S}}$. Some earthquakes are represented by several records compiled from different source catalogs. In these cases, the preferred origin time, epicenter, and magnitude are selected from the different records according to the criteria described below.

Foreshocks and aftershocks as identified in the source catalogs are excluded (table 2). In addition, some earthquakes once thought to have occurred in SCR crust are now recognized as being in ACRs (table 3) and are also excluded. Most of these are in eastern China (fig. 1). Five events were found in only one source catalog and could not be confirmed as earthquakes (table 4).

\section{Preference Hierarchy for Origin Time, Epicenter, and Mw}

Table 5 summarizes the preference hierarchy used to select values for inclusion in this report and W13B. The preferred sources of origin times and epicenters are GEM followed by C08 because of their improved computational methodologies (Engdahl and others, 1998; Engdahl and Villasenor, 2002; Storchak and others, 2012). In recent years, ISC (the International Seismological Centre in England) has used computational methods like those of $\mathrm{C} 08$ (accessed on February 7, 2014 at http://www.isc.ac.uk/).

Preferred $\mathrm{M}_{\mathrm{WS}}$ are derived from scalar moment, $\mathrm{M}_{0}$, where available. The preferred scalar moments are those of CMT (accessed on February 7, 2014 at http://www.globalcmt.org/). The second preference is for scalar-moment values listed and evaluated by Johnston (1996a). MW values calculated by conversion from other magnitudes are only used for W13B when no scalar moments are listed by CMT and Johnston (1996a). When required, nearly all conversions use the regression equations of Johnston (1996a, b). If no scalar moment or $\mathrm{M}_{\mathrm{S}}$ is available, $\mathrm{M}_{\mathrm{W}}$ is calculated by conversion from other types of data as ranked in table 5. GEM conversions are least preferred for application to SCR earthquakes because the data that control the conversion equations come mostly from ACRs and plate boundaries.

W13B is restricted to earthquakes in the continental crust, the thickness of which varies around the globe (Mooney and others, 2002). Most SCR hypocentral depths reported in the catalogs of table 1 are a few tens of kilometers or less and so this report takes maximum crustal thickness in SCRs to be 50 $\mathrm{km}$. This cutoff excludes a few questionably deep earthquakes in the mantle and subduction zones, while capturing most or all crustal earthquakes in areas of thick SCR crust. Given the scarcity of sourcecatalog depths greater than 50 kilometers $(\mathrm{km})$ within the mapped boundaries of SCRs, SCR earthquakes lacking depth values are assumed to be crustal.

For SCR earthquakes with multiple cataloged depths, the GEM catalog followed by the C08 catalog are given the highest preferences owing to the improved relocation algorithms used (Engdahl and Villasenor, 2002; Villasenor and Engdahl, 2005, 2007; Storchak and others, 2012) relative to older catalogs. J94 is given third preference because it reports all published depths that the compilers could find and identifies a preferred value for each earthquake. Next preferences are for depths listed by PDE (U.S. Geological Survey's Preliminary Determinations of Epicenters), SM05, and TS97, in that order. Last preference for SCR earthquakes is given to depths that GR54 (Gutenberg and Richter, 1954) lists as "shallow" ("depth does not exceed $60 \mathrm{~km}$," GR54, p. 10). 


\section{Magnitude Conversion}

\section{$M_{0}$ to $M_{w}$}

As noted in the preceding section, CMT is the preferred source of a scalar moment $\mathrm{M}_{0}$ and its resulting $\mathrm{M}_{\mathrm{W}}$. Estimates of the uncertainties of CMT moments are from Johnston (1996a). Table B2 in Appendix A of Johnston (1996a) lists $\log \left(\mathrm{M}_{0}\right)$ and its uncertainty " $U$," where the standard deviation of $\mathrm{M}_{\mathrm{W}}$ is $\sigma=(2 / 3) \log (\mathrm{U})$ (see derivation in Appendix A of Johnston [1996a]). The table lists more than one published value of $\mathrm{M}_{0}$ for most of the listed earthquakes. For each of these earthquakes, in order to select a best value and assign it a value of $U$, Johnston considers the quality of data and the analytical method used to calculate each moment value and the number and consistency of independent moment values. Johnston assigns $U=1.6$ to most CMT moments in his table B2. Accordingly, this report uses the same value for all CMT moments in catalog W13B, so that $\sigma=0.14$ for CMT magnitudes that are not included in Johnston (1996a).

The source of scalar moments for earthquakes lacking a CMT value is table B2 of Johnston (1996a). Johnston calculated $\mathrm{M}_{\mathrm{W}}$ with the equation $\mathrm{M}_{\mathrm{W}}=(2 / 3)\left(\log \left[\mathrm{M}_{0}\right]\right)-10.7$ (Hanks and Kanamori, 1979). Around 2005, the USGS and others changed the equation by moving the 10.7 inside the parentheses to reduce roundoff errors, giving $\mathrm{M}_{\mathrm{W}}=(2 / 3)\left(\log \left[\mathrm{M}_{0}\right]-16.101\right)$ (accessed on February 7 , 2014 at http://www.globalcmt.org/CMTsearch.html and at http://colossus.iris.washington.edu/docs/papers/download/Summary_WG_recommendations_20130327. $p d f)$. This report uses the newer equation, with the result that six earthquakes in $\mathrm{W} 13 \mathrm{~B}$ have $\mathrm{M}_{\mathrm{W}}$ values that are 0.1 unit greater than the values listed by Johnston (1996a).

Johnston (1996a, table B2) does not list the Valentine, Texas earthquake of August 16, 1931, and therefore does not estimate $U$ for it. Metzger and Johnston (1994), however, quote a moment determination of $3.3 \times 10^{25}$ dyne-cm from Doser (1987). Johnston (1996a, table B2) lists U values for seven other North American SCR earthquakes that were analyzed by computational methods similar to those of Doser (1987). The median of the seven $U$ values is 2.0, which this report uses as $U$ for the Valentine earthquake. This value gives $\sigma=0.20$ for the Valentine earthquake.

\section{$M_{s}$ to $M_{w}$}

For conversion of surface-wave magnitude, $\mathrm{M}_{\mathrm{S}}$ to $\mathrm{M}_{\mathrm{W}}$, this report uses the regression equations and look-up tables of Johnston (1996a). The equations and tables give values of both $\mathrm{M}_{\mathrm{W}}$ and its standard deviation. The two preferred sources of $\mathrm{M}_{\mathrm{S}}$ values are the preferred values of $\mathrm{C} 08$, followed by those that the ISC lists as calculated by ISC (table 5). For each earthquake, the compilers of C08 considered all published magnitudes and applied criteria described by Engdahl and Villasenor (2002) to select one magnitude as preferred. For these earthquakes, W13B cites C08 as the source. If C08 lists only one published magnitude, and for the three groups of earthquakes discussed in the next paragraphs, this report cites the original catalog as the source.

Three small groups of earthquakes require special treatment. First, C08 lists several preferred magnitudes as $\mathrm{M}_{\mathrm{W}}$ from Pacheco and Sykes (1992). For earthquakes lacking published $\mathrm{M}_{0}$ values, Pacheco and Sykes (1992) use the regression equation of Ekstrom and Dziewonski (1988) to convert published $\mathrm{M}_{\mathrm{S}}$ values to $\log \left(\mathrm{M}_{0}\right)$. However, Ekstrom and Dziewonski (1988) derive their regression using a global earthquake catalog; their equation is therefore more appropriate for use with plateboundary and ACR earthquakes. In contrast, Johnston (1996a) develops a regression equation solely from SCR earthquakes. $\mathrm{M}_{\mathrm{W}}$ from the equations of Ekstrom and Dziewonski (1998) exceeds $\mathrm{M}_{\mathrm{W}}$ from the Johnston (1996a) equation by 0.1 unit in the range $M_{S} 6.0-7.1$, and is smaller by 0.1 unit for $M_{S}$ 
7.8-8.0. Accordingly, where $\mathrm{C} 08$ lists a preferred $\mathrm{M}_{\mathrm{W}}$ from Pacheco and Sykes, $\mathrm{M}_{0}$ is recalculated using Johnston's (1996a) equation.

Second, for a few earthquakes, $\mathrm{C} 08$ lists body-wave magnitude $\left(\mathrm{m}_{\mathrm{B}}\right)$ as the preferred magnitude. Johnston (1996a) does not give a conversion equation from $\mathrm{m}_{\mathrm{B}}$ to $\log \left(\mathrm{M}_{0}\right)$. Following Engdahl and Villasenor (2002), $\mathrm{m}_{\mathrm{B}}$ is treated as an adequate approximation to $\mathrm{M}_{\mathrm{S}}$ for earthquakes shallower than 60 $\mathrm{km}$, and $\mathrm{m}_{\mathrm{B}}$ is converted directly to $\log \left(\mathrm{M}_{0}\right)$ using the equation of Johnston (1996a). As explained in the earlier section on "Preference Hierarchy for Origin Time, Epicenter, and $\mathrm{M}_{\mathrm{W}}$," Johnston's equation is preferred over GEM's because the latter is dominated by ACR and plate-boundary earthquakes.

Third, if no magnitude of any kind is available in the PDE, C08, or ISC catalogs, the method used in this report is to follow Johnston (1994, p. 3-18) and prefer Gutenberg and Richter's (1954) $M_{S}$ value over $\mathrm{M}_{\mathrm{S}}$ from other sources that have not been as thoroughly reviewed. The values reported by Gutenberg and Richter (1954) are decreased by 0.2 to remove the bias reported by Abe (1981), Ambraseys and Douglas (2004), and Engdahl and Villasenor (2002).

\section{Other Instrumental Data to $\mathrm{M}_{\mathrm{w}}$}

Johnston (1996a, b) derived regression equations and look-up tables for converting teleseismic body-wave magnitude $\left(\mathrm{m}_{\mathrm{b}}\right)$, regional magnitude $\left(\mathrm{m}_{\mathrm{bLg}}\right)$, local magnitude $\left(\mathrm{M}_{\mathrm{L}}\right)$, and the number of International Seismological Summary (ISS) stations that reported an earthquake. This report does not contain estimates of $\mathrm{M}_{\mathrm{W}}$ from the fraction of operating ISS stations that reported an earthquake. Such $\mathrm{M}_{\mathrm{W}}$ values have larger $\sigma$ than $\mathrm{M}_{\mathrm{W}}$ converted from $\mathrm{M}_{\mathrm{S}}, \mathrm{m}_{\mathrm{b}}, \mathrm{m}_{\mathrm{bLg}}$, or $\mathrm{M}_{\mathrm{L}}$ (table A1 of Johnston, 1996b). As explained later in "Multiple Estimates to $\mathrm{M}_{\mathrm{W}}$," two or more individual $\mathrm{M}_{\mathrm{W}}$ estimates of different kinds can be combined into a single overall estimate. The large $\sigma$ from the reporting fraction causes the combined $\mathrm{M}_{\mathrm{W}}$ to vary negligibly according to whether or not the reporting fraction is used. For example, 22 of the earthquakes in W13B have the reporting fraction but no value of Mo, as well as one or more other estimates of $\mathrm{M}_{\mathrm{W}}$ (Metzger and Johnston, 1994). Inclusion of the reporting fraction changes the combined $\mathrm{M}_{\mathrm{W}}$ by an average of 0.04 units (median of 0.05 ) and the associated $\sigma$ by an average of 0.02 units (median of 0.01 ).

\section{Intensity Data to $\mathrm{Mw}_{\mathrm{w}}$}

The reported measures of the sizes of most moderate to large, pre-instrumental SCR earthquakes include the largest reported intensity value (Imax), isoseismal area A, or the radius R of a circle of area A. Most intensities are Modified Mercalli intensities (MMI). Rossi-Forel intensities are converted to MMI values with the table of Richter (1958, p. 651; also paper issues of the PDE catalog) as necessary.

Johnston (1996b) provides regression equations and look-up tables for conversion of $\log (\mathrm{A})$ and Imax to $M_{W}$ and its $\sigma$. The data sheets of Metzger and Johnston (1994) list some published values of A and R. However, the data sheets generally list $\mathrm{M}_{\mathrm{W}}$ values that are based on Johnston's (1996b) remeasurements of A, as shown in his unpublished work sheets (A.C. Johnston, University of Memphis, Memphis, Tennessee, oral and written communs., 2009-2011) and therefore it is advisable to use Johnston's (1996b) values of A (table 5). Imax is not necessarily the epicentral intensity $\mathrm{I}_{0}$ in all cases. For example, some epicenters are located offshore or in sparsely settled areas. If the highest intensity values are in coastal towns or if isoseismals are centered offshore, Imax is used for this report only if no other data are available.

Some early magnitudes were estimated in different ways from intensity data. The preferred magnitudes for inclusion in W13B are those of N.N. Ambraseys (Ambraseys, 1988; Ambraseys and others, 1994; Metzger and Johnston, 1994; Ambraseys and Douglas, 2004). These reports develop region-specific regression relations of $\mathrm{M}_{\mathrm{S}}$ as functions of intensity levels and the radii of circles that are 
equivalent to the corresponding isoseismal areas (Ambraseys and others, 1994). Johnston (1994, p. 33-3-6) cites other regional catalogs whose authors use intensity data in unstated ways to produce approximate equivalents of $\mathrm{M}_{\mathrm{S}}$. All of these estimates are to be treated as $\mathrm{M}_{\mathrm{S}}$, converted to $\mathrm{M}_{\mathrm{W}}$ with the look-up table of Johnston (1996a), and Johnston's method is followed (1994, p. 3-18) in assigning $\mathrm{M}_{\mathrm{W}}$ a large $\sigma$ of 0.5 . Except for the values of Ambraseys in the reports cited earlier in this paragraph, the qualitative intensity-based estimates are used only as a last resort. For example, an explorer wrote a colorful description of what he felt, saw, and heard in western Australia on December 15, 1873. A century later, an analyst interpreted the report and assigned the earthquake $\mathrm{M}_{\mathrm{L}} 6$ (Metzger and Johnston, 1994 , p. AU-5). In this case, $\sigma=1.2$ was assigned to " $\mathrm{M}_{\mathrm{W}}$ estimated by judgment" after Johnston (1994, p. 3-18).

A moderate Australian earthquake in 1885 reportedly formed a 32-km-long scarp (Metzger and Johnston, 1994). Intensity data are few, and Metzger and Johnston (1994) calculated $\mathrm{M}_{\mathrm{W}}$ solely from the scarp length. The same has been done for this report, with the equation of Leonard (2010) for dip-slip SCR earthquakes, instead of the older and widely cited relations of Wells and Coppersmith (1994). The Wells and Coppersmith (1994) equations are dominated by earthquakes that occurred in active continental crust, oceanic crust, and plate boundaries.

\section{Multiple Estimates to $\mathrm{Mw}$}

Most early instrumental SCR earthquakes lack values of scalar moment and $\mathrm{M}_{\mathrm{S}}$ in the PDE, $\mathrm{C} 08$, and ISS catalogs. However, the earthquakes may have two or more convertible values of $\mathrm{m}_{\mathrm{b}}, \mathrm{M}_{\mathrm{L}}$, or $\mathrm{M}_{\mathrm{S}}$ from sources that are less preferred than PDE, C08, or ISS. Pre-instrumental earthquakes can have values of Imax and one to several values of A or R from various isoseismals. Early instrumental earthquakes may have both instrumental and intensity estimates. Johnston (1996b, equations 15-18) describes how to combine two or more individual $\mathrm{M}_{\mathrm{W}}$ estimates in a weighted average, by weighting each $\mathrm{M}_{\mathrm{W}}$ by the reciprocal of its variance $(\sigma)^{2}$. The standard deviation $\sigma$ of the combined $\mathrm{M}_{\mathrm{W}}$ is calculated as the inverse square root of the sum of the weights. In this way, the least certain $\mathrm{M}_{\mathrm{W}}$ estimates have the smallest weights, and the least influence on the combined magnitude and its standard deviation. EPRI and others (2012, p. 3-15, 3-22, and 3-36) used the same variance-weighting method. Bevington and Robinson (1992, p. 59) describe a more generalized version of this approach.

Johnston (1996b) notes that combining two or more $\mathrm{M}_{\mathrm{W}}$ estimates of different types sometimes results in a combined standard deviation that is smaller than might be expected from the individual $\sigma$ values. Examination of Johnston (1994, p. 3-18) and the look-up tables of Johnston (1996a, b) show that nearly all estimates of individual standard deviations are less than 1.0. Because of weighting by the reciprocal of variance, the most certain estimates will have smaller standard deviations, larger weights, and greater influence on the combined $\mathrm{M}_{\mathrm{W}}$ and its $\sigma$. Certain estimates thereby tend to decrease the combined $\sigma$. A reasonable interpretation of this effect is that increasing the number of constraints on the combined $\mathrm{M}_{\mathrm{W}}$ tends to reduce its uncertainty. (See table 6 for a list of $37 \mathrm{SCR}$ earthquakes from catalog $\mathrm{W} 13 \mathrm{~B}$, each of which has two or more different kinds of estimates of $\mathrm{M}_{\mathrm{W}}$, each with an associated $\sigma$.) Thirty-four SCR earthquakes (including the three earthquakes whose combined $\mathrm{M}_{\mathrm{W}}$ values are 7.0 or larger [IN-1819-0616, NA-1812-0207, and NA-1886-0901]) have combined $\sigma$ that is smaller than any individual $\sigma$ that contributes to the $\sigma$ value. Additionally, Part A of this report lists four prehistoric earthquakes for which the combined $\sigma$ values are smaller than the associated individual values. However, the decrease in uncertainty of combined $\mathrm{M}_{\mathrm{W}}$ is not universal. Three of the $37 \mathrm{SCR}$ earthquakes have at least one individual $\sigma$ smaller than or equal to the corresponding combined $\sigma$ : IB1903-0809, IN-1927-0602, and NA-1870-1020. 
It is also necessary to consider whether to combine all available $\mathrm{M}_{\mathrm{W}}$ estimates for a particular earthquake, or just the best few estimates. The first option provides more constraints on the combined $\mathrm{M}_{\mathrm{W}}$, whereas the second option provides tighter constraints. This report uses the second option. Given two or more examples of the same kind for the same earthquake (for example, two isoseismal maps or three calculations of $\mathrm{M}_{\mathrm{S}}$ ), one was selected by following the guidelines described earlier (see "Preference Hierarchy for Origin Time, Epicenter, and $\mathrm{M}_{\mathrm{W}}$ " and table 5). In contrast, given values of both $\mathrm{M}_{\mathrm{S}}$ and $\mathrm{m}_{\mathrm{b}}$ for the same earthquake both values can be used because they are calculated from different properties of the seismogram.

Given two analyses of intensity data by different seismologists, preference is given to a map showing MMI over one showing Rossi-Forel intensities, a map showing more isoseismal areas or radii, or a map whose isoseismal shapes suggest more control points or less smoothing. Preference is also given to a map showing only one isoseismal over an estimate of Imax alone. If an isoseismal and Imax are both available but one is clearly more poorly constrained, the better-constrained one is used.

Johnston (1996b) argues that interpretation of intensity reports and drawing of isoseismals are more subject to systematic errors than are $\mathrm{M}_{\mathrm{W}}$ estimates from Imax or instrumental data. Johnston's equation 18 and its accompanying discussion show how systematic errors can be incorporated in $\mathrm{M}_{\mathrm{W}}$ based on isoseismal data. See table 6 for the combined estimates of $\mathrm{M}_{\mathrm{W}}$ and their associated standard deviations. Also see table 7 for published but excluded $\mathrm{M}_{\mathrm{W}}$ estimates for notable earthquakes, together with the reasons for their exclusion.

\section{Asymmetric Uncertainty in Magnitude}

Ultimately, CEUS Mmax may be estimated from the shapes of histograms of SCR $\mathrm{M}_{\mathrm{W}}$ values like those in figure 3 of Petersen and others (2008). However, given an earthquake with magnitude $\mathrm{M}_{\mathrm{W}}$, there are, in most cases, more earthquakes with size $\mathrm{M}_{\mathrm{W}}-0.1$ than those with size $\mathrm{M}_{\mathrm{W}}+0.1$, and the true magnitude is likely smaller than $\mathrm{M}_{\mathrm{W}}$. The count of $\mathrm{M}_{\mathrm{W}}$ values in any given bin of a histogram will therefore be biased upward (Tinti and Mulargia, 1985). Tinti and Mulargia assume that the uncertainties in magnitude are normally distributed with standard deviation $\sigma$ and calculate the bias of an individual magnitude as $\left(b^{2} \sigma^{2}\right) /(2 \log [e])$, where $b$ is the slope of a magnitude-frequency graph.

It is not necessary to correct this bias here, because the bias correction is applied to individual $\mathrm{M}_{\mathrm{W}}$ values first, and then to a bin count by multiplying the bias by the bin count (McGuire, 2004, p. 44 45). For hazard computations, bin counts are often in the hundreds (EPRI and others, 2012, p. 3-11-316). In contrast, the bins in the histograms of Petersen and others (2008) contain at most eight $\mathrm{M}_{\mathrm{W}}$ values each. For $b=1$ and $\sigma=0.2$, typical values for the earthquakes compiled in W13B, the expression in the previous paragraph gives an upward bias of each magnitude of 0.046 . For a bin count of eight, correcting the bias would decrease the bin count by $8 \times 0.046=0.37$, and bins with smaller counts would require smaller bias corrections. No individual earthquake would move from one magnitude bin to the next lower bin.

\section{Conclusions}

1. Table 8 (see electronic supplement) contains the final catalog W13B. It lists 153 historical SCR earthquakes. For each earthquake, the table lists date, origin time, epicenter, $\mathrm{M}_{\mathrm{W}}$ and the kind or kinds of data from which it was calculated, the standard deviation of $\mathrm{M}_{\mathrm{W}}$, the source of each piece of information, and additional information needed to use the earthquake in Mmax estimation.

2. As pointed out by Johnston (1996b) and illustrated in table 6, if estimates of an earthquake's $\mathrm{M}_{\mathrm{W}}$ can be obtained from each of two or more different kinds of instrumental or intensity data, then the 
estimates can be combined to yield multiply-constrained estimates of $\mathrm{M}_{\mathrm{W}}$ and its standard deviation $\sigma$. The combined estimate of $\sigma$ can be smaller than some or even all of the individual estimates, thereby decreasing the uncertainty of $\mathrm{M}_{\mathrm{W}}$.

\section{Acknowledgments}

I thank A.C. Johnston for copies of his unpublished data sheets for magnitude calculations and for TIFF files containing scans of the colored plates of Broadbent and Allan Cartography (1994); T. Allen for bringing the TIFF files into ArcMap software for processing; and K.G. Mackey for the largemagnitude part of the huge catalog of eastern Russia that he and his colleagues developed, and for guidance in its use. Reviews by P. Powers and C.S. Mueller improved the manuscript.

\section{References Cited}

Abe, Keiiti, 1981, Magnitudes of large shallow earthquakes from 1904 to 1980: Physics of the Earth and Planetary Interiors, v. 27, p. 72-92.

Abe, Keiiti, 1984, Complements to "Magnitudes of large shallow earthquakes from 1904 to 1980":

Physics of the Earth and Planetary Interiors, v. 34, p. 17-23.

Abe, Katsuuki, and Noguchi, Shin'ichi, 1983a, Determination of magnitude for large shallow earthquakes 1898-1917: Physics of the Earth and Planetary Interiors, v. 32, p. 45-59.

Abe, Katsusuki, and Noguchi, Shin'ichi, 1983b, Revision of magnitudes of large shallow earthquakes, 1897-1912: Physics of the Earth and Planetary Interiors, v. 33, p. 1-11.

Ambraseys, N.N., 1988, Engineering seismology: Earthquake engineering and structural dynamics, v. 19 , p. 1-105.

Ambraseys, N.N., and Adams, R.D., 1991, Reappraisal of major African earthquakes, south of $20^{\circ}$ N, 1900-1930: Natural Hazards, v. 4, p. 389-419.

Ambraseys, N.N., and Douglas, J., 2004, Magnitude calibration of north Indian earthquakes:

Geophysical Journal International, v. 159, p. 165-206.

Ambraseys, N.N., Melville, C.P., and Adams, R.D., 1994, The seismicity of Egypt, Arabia and the Red Sea-A historical review: Cambridge, U.K., Cambridge University Press, 181 p.

Bakun, W.H., and Hopper, M.G., 2004, Magnitudes and locations of the 1811-1812 New Madrid, Missouri, and the 1886 Charleston, South Carolina, earthquakes: Bulletin of the Seismological Society of America, v. 94, no. 1, p. 64-75.

Bakun, W.H., Johnston, A.C., and Hopper, M.G., 2003, Estimating locations and magnitudes of earthquakes in eastern North America from Modified Mercalli intensities: Bulletin of the Seismological Society of America, v. 93, no. 1, p. 190-202.

Basham, P.W., Weichert, D.H., Anglin, F.M., and Berry, M.J., 1982, New probabilistic strong seismic ground motion maps of Canada-A compilation of earthquake source zones, methods and results: Earth Physics Branch, Energy, Mines and Resources Canada Open File Number 82-33, 205 p. Basham, P.W., Weichert, D.H., and Berry, M.J., 1979, Regional assessment of seismic risk in eastern Canada: Bulletin of the Seismological Society of America, v. 69, no. 5, p. 1567-1602.

Bevington, P.R., and Robinson, D.K., 1992, Data reduction and error analysis for the physical sciences (2 ed.): New York, McGraw-Hill, Inc., 328 p.

Bilham, Roger, 1998, Slip parameters for the Rann of Kachchh, India, 16 June 1819, earthquake, quantified from contemporary accounts, in Stewart, I.S., and Vita-Finzi, C., eds., Coastal tectonics: London, England, Geological Society Special Publication 146, p. 295-319. 
Bilham, Roger, Fielding, E., Hough, Susan, Rajendran, Chittenipattu Puthenveettil, and Rajendran, Kusala, 2003, A reevaluation of the Allah Bund 1819 earthquake using the 2001 Bhuj earthquake as a template [abs.]: Seismological Research Letters, v. 74, no. 2, p. 217.

Bollinger, G.A., 1977, Reinterpretation of the intensity data for the 1886 Charleston, South Carolina, earthquake, in Rankin, D.W., ed., Studies related to the Charleston, South Carolina, earthquake of 1886-A preliminary report: U.S. Geological Survey Professional Paper 1028, p. 17-32.

Boyd, O.S., and Cramer, C.H., 2014, Estimating earthquake magnitudes from reported intensities in the Central and Eastern United States: Bulletin of the Seismological Society of America, v. 104, no. 4, p. 1709-1722.

Broadbent, Tanya, and Allan Cartography, 1994, Appendix G-Maps of the stable continental regions, in Johnston, A.C., Coppersmith, K.J., Kanter, L.R., and Cornell, C.A., eds., The earthquakes of stable continental regions: Palo Alto, California, Electric Power Research Institute, v. 5, 2,519 p., 16 folded plates, 1 diskette.

Campbell, K.W., 1986, An empirical estimate of near-source ground motion for a major, $\mathrm{m}_{\mathrm{b}}=6.8$, earthquake in the eastern United States: Bulletin of the Seismological Society of America, v. 76, no. 1, p. $1-17$.

Chinnery, M.A., 1979, Investigations of the seismological input to the safety design of nuclear power reactors in New England: U.S. Nuclear Regulatory Commission report NUREG/CR-0563, 72 p.

Coppersmith, K.J., 1994, Introduction, in Johnston, A.C., Coppersmith, K.J., Kanter, L.R., and Cornell, C.A., eds., The earthquakes of stable continental regions, v. 1: Palo Alto, California, Electric Power Research Institute, p. 1-1-1-10. [report contains 5 volumes, 2519 pages, 16 folded plates, and 1 diskette]

Coppersmith, K.J., Johnston, A.C., and Arabasz, W.J., 1987, Estimating maximum earthquakes in the central and eastern United States-A progress report, in Jacob, K.H., ed., Proceedings from the symposium on seismic hazards, ground motions, soil-liquefaction and engineering practice in eastern North America: Tuxedo, N.Y., National Center for Earthquake Engineering Research Technical Report NCEER-87-0025, p. 217-232.

Cramer, C.H., and Boyd, O.S., in press, Why the New Madrid earthquakes are M7-8 and the Charleston earthquake is $\sim \mathrm{M} 7$ : Bulletin of the Seismological Society of America, 48 ms. p.

Doser, D.I., 1987, The 16 August 1931 Valentine, Texas, earthquake-Evidence for normal faulting in West Texas: Bulletin of the Seismological Society of America, v. 77, no. 6, p. 2005-2017.

Ebel, J.E., 1996, The Seveneenth Century seismicity of northeastern North America: Seismological Research Letters, v. 67, no. 3, p. 51-68.

Ebel, J.E., 2006, The Cape Ann, Massachusetts earthquake of 1755-A 250th anniversary perspective: Seismological Research Letters, v. 77, no. 1, p. 74-86.

Ebel, J.E., 2011, A new analysis of the magnitude of the February 1663 earthquake at Charlevoix, Quebec: Bulletin of the Seismological Society of America, v. 101, no. 3, p. 1024-1038.

Ebel, J.E., Dupuy, Megan, and Bakun, W.H., 2013, Assessing the location and magnitude of the 20 October 1870 Charlevoix, Quebec, earthquake: Bulletin of the Seismological Society of America, v. 103, no. 1, p. 588-594.

Ekstrom, Goran, and Dziewonski, A.M., 1988, Evidence of bias in estimations of earthquake size: Nature, v. 332, p. 319-323.

Electric Power Research Institute (EPRI), United States Department of Energy, and United States Nuclear Regulatory Commission, 2012, Technical report-Central and Eastern United States seismic source characterization for nuclear facilities: Palo Alto, Calif., Electric Power Research Institute, United States Department of Energy, and United States Nuclear Regulatory Commission, 6 v. 
Engdahl, E.R., van der Hilst, Rob, and Buland, Raymond, 1998, Global teleseismic earthquake relocation with improved travel times and procedures for depth determination: Bulletin of the Seismological Society of America, v. 88, no. 3, p. 722-743.

Engdahl, E.R., and Villasenor, Antonio, 2002, Global seismicity-1900-1999, in Lee, W.H.K., Kanamori, Hiroo, Jennings, P.C., and Kisslinger, Carl, eds., International handbook of earthquake and engineering seismology, part A: Amsterdam, Academic Press, p. 665-690.

Fah, Donat, Gisler, Monika, Jaggi, Bernard, Kastli, Philipp, Lutz, Thomas, Masciadri, Virgilio, Matt, Christoph, Mayer-Rosa, Dieter, Rippmann, DDorothee, Schwartz-Zanetti, Gabriela, Tauber, Jurg, and Wenk, TThomas, 2009, The 1356 Basel earthquake-An interdisciplinary revision: Geophysical Journal International, v. 178, p. 351-374.

Frankel, A.D., Petersen, M.D., Mueller, C.S., Haller, K.M., Wheeler, R.L., Leyendecker, E.V., Wesson, R.L., Harmsen, S.C., Cramer, C.H., Perkins, D.M., and Rukstales, K.S., 2002, Documentation for the 2002 Update of the National Seismic Hazard Maps: U.S. Geological Survey Open-File Report 20020420, 39 p. (accessed on February 7, 2014 at http://pubs.er.usgs.gov/usgspubs/ofr/ofr024203).

Gomberg, Joan, 1993, Tectonic deformation in the New Madrid seismic zone-Inferences from map view and cross-sectional boundary element models: Journal of Geophysical Research, v. 98, no. B4, p. 6,639-6,664.

Gradstein, Felix, Ogg, James, and Smith, Alan, eds., 2004, A geologic time scale 2004: Cambridge, United Kingdom, Cambridge University Press, 589 p., 1 folded plate.

Gutenberg, Beno, and Richter, C.F., 1954, Seismicity of the Earth: Princeton, New Jersey, Princeton University Press, 310 p.

Hamdache, M., Pelaez, Jose A., Talbi, A., and Lopez Casado, C., 2010, A unified catalog of main earthquakes for northern Algeria from A.D. 856 to 2008: Seismological Research Letters, v. 81, no. 5, p. 732-739.

Hanks, T.C., and Kanamori, Hiroo, 1979, A moment magnitude scale: Journal of Geophysical Research, v. 84, no. B5, p. 2348-2350.

Heidari, Tahereh, and Andrus, R.D., 2010, Mapping liquefaction potential of aged soil deposits in Mount Pleasant, South Carolina: Engineering Geology, v. 112, p. 1-12.

Holzer, T.L., Noce, T.E., and Bennett, M.J., 2010, Regional strong motion during the 1811-12 New

Madrid earthquakes inferred from paleoliquefaction: Geological Society of America Abstracts with Programs, v. 42, no. 5, p. 219.

Holzer, T.L., Noce, T.E., and Bennett, M.J., 2011, Implications of liquefaction caused by the 1811-12 New Madrid earthquakes for estimates of ground shaking and earthquake magnitudes [abs.]:

Seismological Research Letters, v. 82, no. 2, p. 274.

Hough, S.E., Armbruster, J.G., Seeber, Leonardo, and Hough, J.F., 2000, On the Modified Mercalli intensities and magnitudes of the 1811-1812 New Madrid earthquakes: Journal of Geophysical Research, v. 105, no. B10, p. 23839-23864.

Hough, S.E., and Page, Morgan, 2011, Toward a consistent model for strain accrual and release for the New Madrid seismic zone, central United States: Journal of Geophysical Research, v. 116, no. B03311, doi:10.1029/2010JB007783, 17 p.

Johnston, A.C., 1994, The stable continental region database, in Johnston, A.C., Coppersmith, K.J., Kanter, L.R., and Cornell, C.A., eds., The earthquakes of stable continental regions, v. 1: Palo Alto, California, Electric Power Research Institute, p. 3-1-3-80. [report contains 5 volumes, 2519 pages, 16 folded plates, and 1 diskette]

Johnston, A.C., 1996a, Seismic moment assessment of earthquakes in stable continental regions-I. Instrumental seismicity: Geophysical Journal International, v. 124, p. 381-414. 
Johnston, A.C., 1996b, Seismic moment assessment of earthquakes in stable continental regions-II.

Historical seismicity: Geophysical Journal International, v. 125, p. 639-678.

Johnston, A.C., 1996c, Seismic moment assessment of earthquakes in stable continental regions-III. New Madrid 1811-1812, Charleston 1886 and Lisbon 1755: Geophysical Journal International, v. 126, p. 314-344.

Johnston, A.C., Coppersmith, K.J., Kanter, L.R., and Cornell, C.A., eds., 1994, The earthquakes of stable continental regions: Palo Alto, California, Electric Power Research Institute, 5 v., 2,519 p., 16 folded plates, 1 diskette.

Kanter, L.R., 1994, Tectonic interpretation of stable continental crust, in Johnston, A.C., Coppersmith, K.J., Kanter, L.R., and Cornell, C.A., eds., The earthquakes of stable continental regions, v. 1: Palo Alto, California, Electric Power Research Institute, p. 2-1-2-98. [report contains 5 volumes, 2519 pages, 16 folded plates, and 1 diskette]

Leonard, Mark, 2010, Earthquake fault scaling-Self-consistent relating of rupture length, width, average displacement, and moment release: Bulletin of the Seismological Society of America, v. 100, no. 5A, p. 1971-1988.

Mackey, K.G., Fujita, K., Hartse, H.E., Stead, R.J., Steck, L.K., Gunbina, L.V., Leyshuk, N., Shibaev, S.V., Koz'min, B.M., Imaev, V.S., Gordeev, E.I., Chebrov, V.N., Masal'ski, O.K., Gileva, N.A., Bormatov, V.A., Voitenok, A.A., Levin, Y.N., and Fokina, T.A., 2010, Seismicity map of eastern Russia, 1960-2010: Seismological Research Letters, v. 81, no. 5, p. 761-768.

McGuire, R.K., 2004, Seismic hazard and risk analysis: Oakland, Calif., Earthquake Engineering Research Institute, $221 \mathrm{p}$.

Metzger, A.G., and Johnston, A.C., 1994, Appendix F-The stable continental region seismicity database, in Johnston, A.C., Coppersmith, K.J., Kanter, L.R., and Cornell, C.A., eds., The earthquakes of stable continental regions, v. 3, 4: Palo Alto, California, Electric Power Research Institute, 5 v., 2,519 p., 16 folded plates, 1 diskette.

Mooney, W.D., Prodehl, Claus, and Pavlenkova, N.I., 2002, Seismic velocity structure of the continental lithosphere from controlled source data, in Lee, W.H.K., Kanamori, Hiroo, Jennings, P.C., and Kisslinger, Carl, eds., International Handbook of Earthquake and Engineering Seismology: Amsterdam, The Netherlands, Academic Press, p. 887-910.

Mueller, Karl, and Pujol, Jose, 2001, Three-dimensional geometry of the Reelfoot blind thrustImplications for moment release and earthquake magnitude in the New Madrid seismic zone: Bulletin of the Seismological Society of America, v. 91, no. 6, p. 1563-1573.

Nuttli, O.W., 1973a, The Mississippi Valley earthquakes of 1811 and 1812-Intensities, ground motion, and magnitudes: Bulletin of the Seismological Society of America, v. 63, p. 227-248.

Nuttli, O.W., 1974, Magnitude-recurrence relations for central Mississippi Valley earthquakes: Bulletin of the Seismological Society of America, v. 64, p. 1189-1207.

Nuttli, O.W., 1983, Average seismic source-parameter relations for mid-plate earthquakes: Bulletin of the Seismological Society of America, v. 73, no. 2, p. 519-535.

Pacheco, J.F., and Sykes, L.R., 1992, Seismic moment catalog of large shallow earthquakes, 1900 to 1989: Bulletin of the Seismological Society of America, v. 82, no. 3, p. 1306-1349.

Petersen, M.D., Frankel, A.D., Harmsen, S.C., Mueller, C.S., Haller, K.M., Wheeler, R.L., Wesson, R.L., Zeng, Yuehua, Boyd, O.S., Perkins, D.M., Luco, Nico, Field, E.H., Wills, C.J., and Rukstales, K.S., 2008, Documentation for the 2008 update of the United States National Seismic Hazard Maps: U.S. Geological Survey Open-File Report 2008-1128, 119 p., http://pubs.usgs.gov/of/2008/1128/.

Petersen, M.D., Moscetti, M.P., Powers, P.P., Mueller, C.S., Haller, K.M., Frankel, A.D., Zeng, Yuehua, Resaeian, Sanaz, Harmsen, S.C., Boyd, O.S., Field, Ned, Chen, Rui, Rukstales, K.S., Luco, 
Nico, Wheeler, R.L., Williams, R.A., and Olsen, A.H., 2014, Documentation for the 2014 update of the United States National Seismic Hazard Maps: U.S. Geological Survey Open-File Report 20141091, 243 p., http://pubs.usgs.gov/of/2014/1091/.

Quittmeyer, R.C., and Jacob, K.H., 1979, Historical and modern seismicity of Pakistan, Afghanistan, northwestern India, and southeastern Iran: Bulletin of the Seismological Society of America, v. 69, p. 773-823.

Rajendran, Chittenipattu Puthenveettil, and Rajendran, Kusala, 2001, Characteristics of deformation and past seismicity associated with the 1819 Kutch earthquake, northwestern India: Bulletin of the Seismological Society of America, v. 91, no. 3, p. 407-426.

Reading, Anya M., 2007, The seismicity of the Antarctic plate, in Stein, Seth, and Mazzotti, Stephane, eds., Continental intraplate earthquakes - Science, hazard, and policy: Boulder, Colo., Geological Society of America Special Paper 425, p. 285-298.

Richter, C.F., 1958, Elementary seismology: San Francisco, Calif., W.H. Freeman and Company, 768 p. Schulte, S.M., and Mooney, W.D., 2005, An updated global earthquake catalog for stable continental regions-Reassessing the correlation with ancient rifts: Geophysical Journal International, v. 161, p. 707-721.

Storchak, D.A., Di Giacomo, Domenico, Bondar, Istvan, Harris, James, Engdahl, E.R., Lee, W.H.K., Villasenor, Antonio, Bormann, Peter, and Ferrari, Graziano, 2012, Final scientific report-ISC-GEM global instrumental earthquake catalog (1900-2009): Thatcham, United Kingdom, International Seismological Centre, 99 p., accessed on February 7, 2014, at http://www.isc.ac.uk.

Szeliga, Walter, Hough, Susan, Martin, Stacy, and Bilham, Roger, 2010, Intensity, magnitude, location, and attenuation in India for felt earthquakes since 1762: Bulletin of the Seismological Society of America, v. 100, no. 2, p. 570-584.

Tinti, Stefano, and Mulargia, Francesco, 1985, Effects of magnitude uncertainties on estimating the parameters in the Gutenberg-Richter frequency-magnitude law: Bulletin of the Seismological Society of America, v. 75, no. 6, p. 1681-1697.

Triep, E.G., and Sykes, L.R., 1997, Frequency of occurrence of moderate to great earthquakes in intracontinental regions-Implications for changes in stress, earthquake prediction, and hazards assessments: Journal of Geophysical Research, v. 102, no. B5, p. 9,923-9,948.

Tuttle, M.P., 2001, The use of liquefaction features in paleoseismology_Lessons learned in the New Madrid seismic zone, central United States: Journal of Seismology, v. 5, p. 361-380.

Tuttle, M.P., 2012, Appendix E-CEUS paleoliquefaction database, uncertainties associated with paleoliquefaction data, and guidance for seismic source characterization, in Electric Power Research Institute, United States Department of Energy, and United States Nuclear Regulatory Commission, eds., Technical report - Central and Eastern United States seismic source characterization for nuclear facilities: Palo Alto, Calif., Electric Power Research Institute, United States Department of Energy, and United States Nuclear Regulatory Commission p. E-1-E-135.

Tuttle, M.P., Hengesh, James, Tucker, K.B., Lettis, William, Deaton, S.L., and Frost, J.D., 2002a, Observations and comparisons of liquefaction features and related effects induced by the Bhuj earthquake: Earthquake Spectra, v. 18, Supplement A, p. 79-100.

Tuttle, M.P., Schweig, E.S., Sims, J.D., Lafferty, R.H., Wolf, L.W., and Haynes, M.L., 2002b, The earthquake potential of the New Madrid seismic zone: Bulletin of the Seismological Society of America, v. 92, p. 2080-2089.

Villasenor, Antonio, and Engdahl, E.R., 2005, A digital hypocenter catalog for the International Seismological Summary: Seismological Research Letters, v. 76, no. 5, p. 554-559. 
Villasenor, Antonio, and Engdahl, E.R., 2007, Systematic relocation of early instrumental seismicityEarthquakes in the International Seismological Summary for 1960-1963: Bulletin of the Seismological Society of America, v. 97, no. 6, p. 1820-1832.

Wells, D.L., and Coppersmith, K.J., 1994, New empirical relationships among magnitude, rupture length, rupture width, rupture area, and surface displacement: Bulletin of the Seismological Society of America, v. 84, p. 974-1002.

Wheeler, R.L., 2009a, Methods of Mmax estimation east of the Rocky Mountains: U.S. Geological Survey Open-File Report 2009-1018, 43 p., http://pubs.usgs.gov/of/2009/1018/.

Wheeler, R.L., 2009b, Sizes of the largest possible earthquakes in the Central and Eastern United States-Summary of a workshop, September 8-9, 2008, Golden, Colorado: U.S. Geological Survey Open-File Report 2009-1263, 304 p., http://pubs.usgs.gov/of/2009/1263/.

Wheeler, R.L., 2011, Reassessment of stable continental regions of Southeast Asia: Seismological Research Letters, v. 82, no. 6, p. 971-983.

Wheeler, R.L., 2014, Earthquake catalog for estimation of maximum earthquake magnitude, Central and Eastern United States-Part A, Prehistoric earthquakes: U.S. Geological Survey Open-File Report 2014-1025-A, 26 p.

Wheeler, R.L., and Frankel, Arthur, 2000, Geology in the 1996 USGS seismic-hazard maps, central and eastern United States: Seismological Research Letters, v. 71, no. 2, p. 273-282. 
Table 1. The five global catalogs and supplementary catalogs used to compile stable continental region earthquakes.

["Source type" distinguishes primary sources, which contain information that has not been reported elsewhere, from secondary sources, which contain information that has been published elsewhere in one or more primary or secondary sources. "Area covered" is worldwide and at all depths unless a more restricted coverage is stated. SCR, stable continental region (Johnston, 1994; Kanter, 1994); km, kilometers. The five "global catalogs searched completely" are listed in preferred search order for records of SCR earthquakes having magnitude at least 6.0 of any magnitude type. For example, C08 contributed only those earthquakes not already found in J94, SM05 added only earthquakes not found in J94 or C08, and so on. - , no acronym because these regional catalogs contributed no earthquakes to the catalog described in this report.]

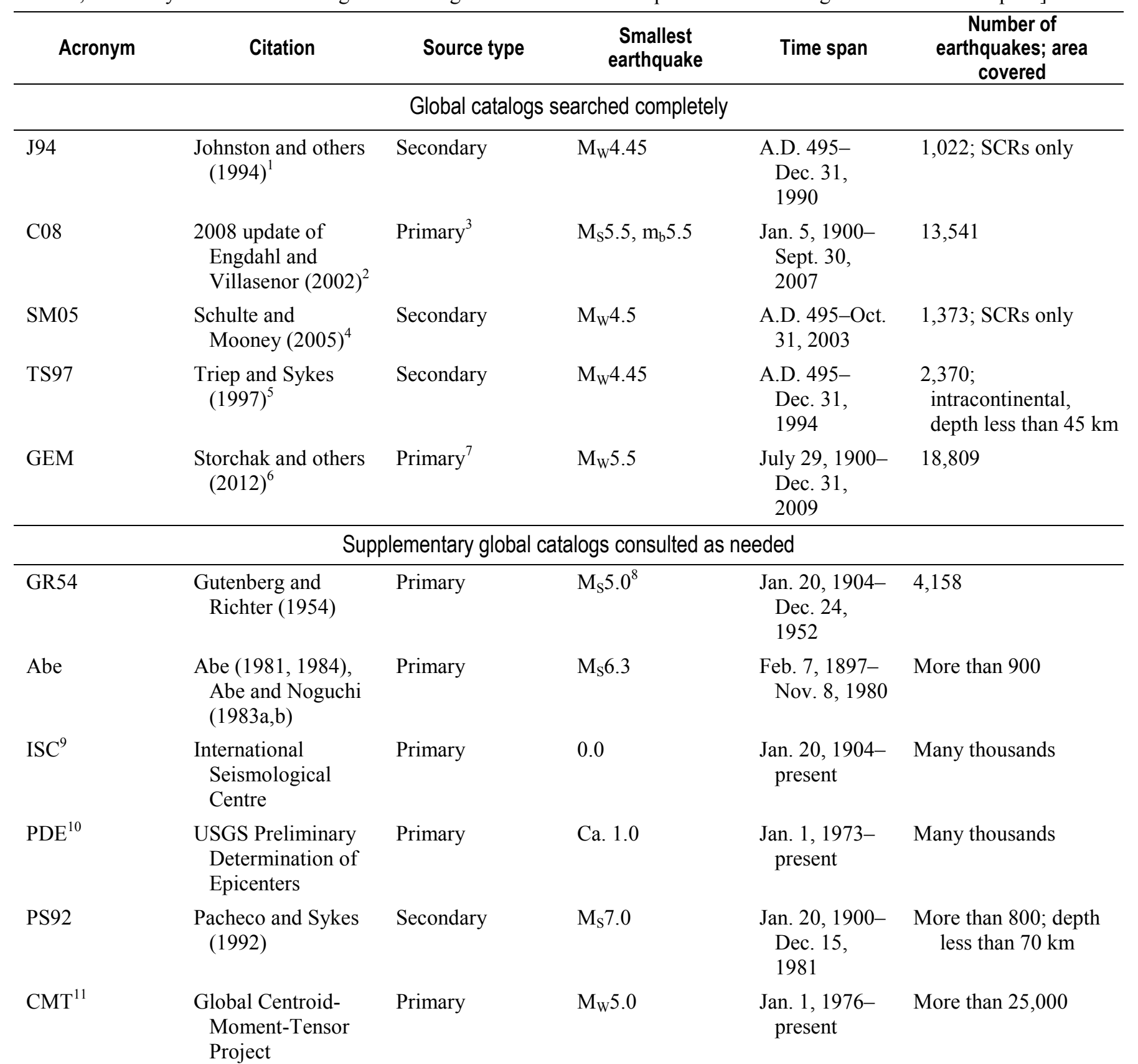


Table 1. The five global catalogs and supplementary catalogs used to compile stable continental region earthquakes.-Continued

\begin{tabular}{|c|c|c|c|c|c|}
\hline Acronym & Citation & Source type & $\begin{array}{l}\text { Smallest } \\
\text { earthquake }\end{array}$ & Time span & $\begin{array}{c}\text { Number of } \\
\text { earthquakes; area } \\
\text { covered }\end{array}$ \\
\hline \multicolumn{6}{|c|}{ Supplementary regional catalogs searched completely } \\
\hline- & Reading (2007) & Secondary & $\mathrm{m}_{\mathrm{b}} 3.5$ & $\begin{array}{l}\text { May 17, } \\
\text { 1980-Feb. } \\
25,2004\end{array}$ & 87; Antarctic plate \\
\hline- & $\begin{array}{l}\text { Hamdache and } \\
\text { others }(2010)\end{array}$ & $\begin{array}{r}\text { Primary and } \\
\text { secondary }\end{array}$ & $\mathrm{M}_{\mathrm{W}} 4.0$ & $\begin{array}{l}\text { A.D. } 856- \\
\text { June, } 2008\end{array}$ & $\begin{array}{l}\text { 923; Northern Algeria } \\
\text { and surroundings }\end{array}$ \\
\hline- & $\begin{array}{l}\text { Mackey and others } \\
\text { (2010) }\end{array}$ & $\begin{array}{l}\text { Primary and } \\
\text { secondary }\end{array}$ & About $\mathrm{m}_{\mathrm{b}} 0.2$ & 1960-2010 & $\begin{array}{l}\text { More than } 333,000 \\
\text { Eastern Russia and } \\
\text { surroundings }\end{array}$ \\
\hline- & $\begin{array}{l}\text { Szeliga and others } \\
\text { (2010) }\end{array}$ & Primary & $\mathrm{M}_{\mathrm{W}} 1.5$ & $\begin{array}{l}\text { Apr. 2, 1762- } \\
\text { Aug. 11, } \\
2009\end{array}$ & $\begin{array}{l}\text { 570; India and } \\
\text { surroundings }\end{array}$ \\
\hline
\end{tabular}

${ }^{1}$ Accessed February 7, 2014 at $h$ ttp://www.epri.com/search/Pages/results.aspx?k=Stable\%20Continental\%20Regions /.

${ }^{2}$ Engdahl and Villasenor (2002) produced a global catalog of twentieth-century earthquakes. Later, the catalog was updated several times with new earthquakes and revised with improved computational methods, the last update and revision being in 2008. The 2008 update was obtained from A. Villasenor (written communs., February 28, 2008 to September 9, 2009).

${ }^{3} \mathrm{C} 08$ is a primary source for most of its origin times, epicenters and depths, and some magnitudes.

${ }^{4}$ Accessed February 7, 2014 at http://earthquake.usgs.gov/research/data/scr_catalog.php.

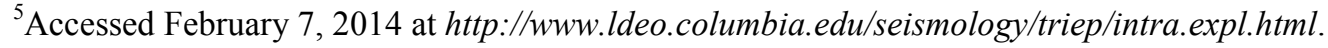

${ }^{6}$ Accessed February 7, 2014 at $h t t p: / / w w w . i s c . a c . u k$. This report uses version 1 of the GEM catalog, which was released on January 31, 2013. Updates through version 1.03, released on June 11, 2013, do not affect SCR earthquakes.

${ }^{7} \mathrm{GEM}$ is a primary source for origin times, epicenters, depths and some magnitudes.

${ }^{8} \mathrm{GR} 54$ values of $\mathrm{M}_{\mathrm{S}}$ are approximately 0.2 units too high (Engdahl and Villasenor, 2002).

${ }^{9}$ Accessed February 7, 2014 at http://www.isc.ac.uk/. Since 1964, the ISC has continued the earlier work of the International Seismological Summary.

${ }^{10}$ Accessed February 7, 2014 at http://earthquake.usgs.gov/earthquakes/eqarchives/epic/. Publication of the PDE was in paper form in and after 1963, changing to digital form at the beginning of 1973. The PDE continues the work of predecessors in other federal agencies.

${ }^{11}$ Accessed February 7, 2014 at http://www.globalcmt.org. 


\section{Table 2. Foreshocks and aftershocks.}

[Earthquake identifiers in columns one and three consist of three parts: (1) the two-letter abbreviation of the name of the stable continental region (SCR) in which the earthquake occurred (fig. 1), (2) the year, and (3) the month and day. If two or more of the listed earthquakes occurred on the same day, then they are identified chronologically as $\mathrm{A}, \mathrm{B}$, and so forth. $\mathrm{M}_{\mathrm{W}}$, moment magnitude from this paper; f, foreshock; a, aftershock. Foreshocks and aftershocks are not listed in tables 6 or 8.]

\begin{tabular}{|c|c|c|c|c|c|c|}
\hline Mainshock & Mw & $\begin{array}{l}\text { Foreshocks or } \\
\text { aftershocks }\end{array}$ & Type & Mw & Source ${ }^{1}$ & Region \\
\hline $\begin{array}{l}\text { AF-1935- } \\
\text { 0419A }\end{array}$ & 6.8 & $\begin{array}{l}\text { AF-1935-0419D } \\
\text { AF-1935-0420 } \\
\text { AF-1939-0123 }\end{array}$ & $\begin{array}{l}\mathrm{a} \\
\mathrm{a} \\
\mathrm{a}\end{array}$ & $\begin{array}{l}6.4 \\
6.4 \\
5.7\end{array}$ & $\begin{array}{l}\text { J94, } \\
\text { SM05 }\end{array}$ & Coastal Libya \\
\hline AF-1990-0520 & $7.1^{2}$ & $\begin{array}{l}\text { AF-1990-0524A } \\
\text { AF-1990-0524B } \\
\text { AF-1990-0709 }\end{array}$ & $\begin{array}{l}\mathrm{a} \\
\mathrm{a} \\
\mathrm{a}\end{array}$ & $\begin{array}{l}6.5 \\
7.1^{2} \\
6.3\end{array}$ & J94 & Southern Sudan \\
\hline $\begin{array}{l}\text { AU-1969- } \\
\text { 0309A }\end{array}$ & 6.6 & AU-1969-0309B & $\mathrm{a}$ & 6.0 & $\begin{array}{l}\text { This } \\
\text { paper }\end{array}$ & New Guinea \\
\hline $\begin{array}{c}\text { AU-1985- } \\
\text { 0915B }\end{array}$ & $6.3^{3}$ & AU-1985-0915A & $\mathrm{f}$ & 6.3 & $\begin{array}{l}\text { This } \\
\text { paper }\end{array}$ & New Guinea \\
\hline $\begin{array}{l}\text { AU-1988- } \\
0122 \mathrm{C}\end{array}$ & 6.6 & $\begin{array}{l}\text { AU-1988-0122A } \\
\text { AU-1988-0122B }\end{array}$ & $\begin{array}{l}\mathrm{f} \\
\mathrm{f}\end{array}$ & $\begin{array}{l}6.2 \\
6.3\end{array}$ & $\begin{array}{l}\text { J94, } \\
\text { SM05 }\end{array}$ & Tennant Creek, Northern Territory, Australia \\
\hline $\begin{array}{l}\text { AU-1995- } \\
\text { 0319B }\end{array}$ & 6.8 & AU-1995-0319A & $\mathrm{f}$ & 6.1 & $\begin{array}{l}\text { This } \\
\text { paper }\end{array}$ & New Guinea \\
\hline EU-1989-0420 & 6.3 & EU-1989-0517 & a & 5.9 & J94 & Southeastern Siberia, Russia. \\
\hline NA-1812-0207 & 7.7 & $\begin{array}{l}\text { NA-1811-1216A } \\
\text { NA-1811-1216B } \\
\text { NA-1812-0123 }\end{array}$ & $\begin{array}{l}\mathrm{f} \\
\mathrm{f} \\
\mathrm{f}\end{array}$ & $\begin{array}{l}7.5 \\
7.2 \\
7.3\end{array}$ & $\begin{array}{l}\text { J94, } \\
\text { SM05 }\end{array}$ & $\begin{array}{l}\text { New Madrid Seismic Zone, Central United } \\
\text { States }\end{array}$ \\
\hline $\begin{array}{l}\text { NA-1933- } \\
1120^{4}\end{array}$ & 7.4 & NA-1934-0831 & a & 6.4 & $\begin{array}{l}\text { J94, } \\
\text { SM05 }\end{array}$ & Baffin Bay, east of Nunavut, Canada \\
\hline $\begin{array}{l}\text { NA-1945- } \\
1108 \mathrm{~A}\end{array}$ & $5.9^{5}$ & NA-1945-1108B & a & $5.9^{5}$ & J94 & Off northeastern coast of Greenland \\
\hline NA-1972-1227 & 6.3 & NA-1972-1121 & $\mathrm{f}$ & 5.9 & J94 & $\begin{array}{l}\text { Queen Elizabeth Islands, northern Nunavut, } \\
\text { Canada }\end{array}$ \\
\hline
\end{tabular}

${ }^{1}$ Source or sources of identification as foreshock or aftershock. J94, Johnston and others (1994); SM05, Schulte and Mooney (2005).

${ }^{2}$ The aftershock had a seismic moment slightly smaller than the main shock.

${ }^{3}$ The foreshock had a seismic moment slightly smaller than the main shock.

${ }^{4}$ The main shock occurred in oceanic crust more than 40 kilometers from the nearest SCR, but the aftershock was only $8 \mathrm{~km}$ from the SCR. Earthquakes having epicenters within 40 kilometers of an SCR boundary are kept in the catalog and classified as transitional (see table 8 and Johnston, 1994). Thus, the main shock is excluded but the aftershock is retained.

${ }^{5}$ Both earthquakes had the same $M_{W}$, but the first was reported by more seismograph stations worldwide (Metzger and Johnston, 1994) and is therefore used in W13B. 
Table 3. Stable continental region earthquakes now recognized as having occurred in active continental crust.

[See table 2 for explanation of earthquake identifiers in column one. Some earthquakes that early data indicated had occurred in stable continental crust (Johnston and others, 1994) are now recognized as having been in active continental crust. These earthquakes are not included in tables 6 or 8. For the African and Indian earthquakes listed below, revised epicenters caused the changes. For the Chinese, North Korean, Indochinese, and Mongolian earthquakes, interpretations of recently published geological and geophysical data indicate that the earthquakes occurred in areas of present-day rifting and associated folding (Wheeler, 2011). Do., ditto]

\begin{tabular}{|c|c|c|c|c|c|}
\hline $\begin{array}{c}\text { Earthquake } \\
\text { identifier }\end{array}$ & Mw & New epicenter & Latitude & Longitude & $\begin{array}{l}\text { Reason for } \\
\text { change }\end{array}$ \\
\hline \multicolumn{6}{|c|}{ Africa (Ambraseys and Adams, 1991) ${ }^{1}$} \\
\hline AF-1903-0604 & 6.4 & East African rift & $0^{\circ} \mathrm{N}$ & $30^{\circ} \mathrm{E}$ & $\begin{array}{l}\text { New intensity } \\
\text { reports, } \\
\text { reassessments of } \\
\text { instrumental data }\end{array}$ \\
\hline AF-1912-0709 & 6.2 & East African rift & $2^{\circ} \mathrm{N}$ & $31^{\circ} \mathrm{E}$ & Do. \\
\hline \multicolumn{6}{|c|}{ Eastern China, North Korea and adjacent seas and bays (Wheeler, 2011)2, 3} \\
\hline CH-1067-1100 & 6.4 & $\begin{array}{l}\text { Coastal } \\
\text { Guangdong } \\
\text { Province }\end{array}$ & $23.6^{\circ} \mathrm{N}$ & $116.5^{\circ} \mathrm{E}$ & Active rifting \\
\hline CH-1548-0913 & 6.4 & Bohai Bay & $38^{\circ} \mathrm{N}$ & $121^{\circ} \mathrm{E}$ & Do. \\
\hline CH-1600-0929 & 6.8 & $\begin{array}{l}\text { Coastal } \\
\text { Guangdong } \\
\text { Province }\end{array}$ & $23.5^{\circ} \mathrm{N}$ & $117^{\circ} \mathrm{E}$ & Do. \\
\hline CH-1604-1229 & 7.7 & Taiwan Strait & $25^{\circ} \mathrm{N}$ & $119.5^{\circ} \mathrm{E}$ & Do. \\
\hline CH-1605-0713 & 7.3 & Hainan Island & $19.9^{\circ} \mathrm{N}$ & $110.5^{\circ} \mathrm{E}$ & Do. \\
\hline CH-1668-0725 & 8.3 & Jiangsu Province & $34.3^{\circ} \mathrm{N}$ & $118.5^{\circ} \mathrm{E}$ & Do. \\
\hline CH-1900-0424 & 6.8 & East China Sea & $27^{\circ} \mathrm{N}$ & $126.5^{\circ} \mathrm{E}$ & Do. \\
\hline CH-1906-0327 & 6.0 & $\begin{array}{l}\text { Coastal Fukien } \\
\text { Province }\end{array}$ & $24.5^{\circ} \mathrm{N}$ & $118.5^{\circ} \mathrm{E}$ & Do. \\
\hline CH-1909-1121 & 7.1 & East China Sea & $25.5^{\circ} \mathrm{N}$ & $122^{\circ} \mathrm{E}$ & Do. \\
\hline CH-1910-0108 & 6.6 & Yellow Sea & $35^{\circ} \mathrm{N}$ & $122^{\circ} \mathrm{E}$ & Do. \\
\hline CH-1918-0213 & 7.4 & $\begin{array}{l}\text { Coastal } \\
\text { Guangdong } \\
\text { Province }\end{array}$ & $23.82^{\circ} \mathrm{N}$ & $117.104^{\circ} \mathrm{E}$ & Do. \\
\hline CH-1919-0601 & 7.1 & East China Sea & $27.074^{\circ} \mathrm{N}$ & $123.315^{\circ} \mathrm{E}$ & Do. \\
\hline CH-1921-1201 & 6.5 & Yellow Sea & $33.7^{\circ} \mathrm{N}$ & $122^{\circ} \mathrm{E}$ & Do. \\
\hline CH-1923-0423 & 6.6 & East China Sea & $26.392^{\circ} \mathrm{N}$ & $127.030^{\circ} \mathrm{E}$ & Do. \\
\hline CH-1927-0203 & 6.5 & Yellow Sea & $33.367^{\circ} \mathrm{N}$ & $121.382^{\circ} \mathrm{E}$ & Do. \\
\hline CH-1929-1024 & 6.3 & South China Sea & $22^{\circ} \mathrm{N}$ & $118^{\circ} \mathrm{E}$ & Do. \\
\hline CH-1931-0115 & 6.6 & East China Sea & $28.497^{\circ} \mathrm{N}$ & $127.137^{\circ} \mathrm{E}$ & Do. \\
\hline CH-1931-0921 & 6.6 & South China Sea & $19.481^{\circ} \mathrm{N}$ & $113.083^{\circ} \mathrm{E}$ & Do. \\
\hline CH-1932-0822 & 6.1 & Yellow Sea & $36.032^{\circ} \mathrm{N}$ & $121.787^{\circ} \mathrm{E}$ & Do. \\
\hline CH-1944-1219 & 6.6 & Korea Bay & $39.887^{\circ} \mathrm{N}$ & $124.148^{\circ} \mathrm{E}$ & Do. \\
\hline
\end{tabular}


Table 3. Stable continental region earthquakes now recognized as having occurred in active continental crust.-Continued

\begin{tabular}{|c|c|c|c|c|c|}
\hline $\begin{array}{l}\text { Earthquake } \\
\text { identifier }\end{array}$ & Mw & New epicenter & Latitude & Longitude & $\begin{array}{c}\text { Reason for } \\
\text { change }\end{array}$ \\
\hline $\mathrm{CH}-1952-0319$ & 6.5 & North Korea & $39^{\circ} \mathrm{N}$ & $125.5^{\circ} \mathrm{E}$ & Do. \\
\hline CH-1962-0318 & 6.0 & $\begin{array}{l}\text { Guangdong } \\
\text { Province }\end{array}$ & $23.820^{\circ} \mathrm{N}$ & $114.639^{\circ} \mathrm{E}$ & Do. \\
\hline CH-1972-0108 & 6.3 & South China Sea & $20.981^{\circ} \mathrm{N}$ & $120.280^{\circ} \mathrm{E}$ & Do. \\
\hline CH-1975-0204 & 6.9 & $\begin{array}{l}\text { Liaoning } \\
\text { Province }\end{array}$ & $40.651^{\circ} \mathrm{N}$ & $122.684^{\circ} \mathrm{E}$ & Do. \\
\hline CH-1984-0521 & 6.0 & Yellow Sea & $32.611^{\circ} \mathrm{N}$ & $121.592^{\circ} \mathrm{E}$ & Do. \\
\hline CH-1986-0725 & 6.1 & East China Sea & $26.528^{\circ} \mathrm{N}$ & $125.997^{\circ} \mathrm{E}$ & Do. \\
\hline CH-1994-0916 & 6.7 & South China Sea & $22.505^{\circ} \mathrm{N}$ & $118.768^{\circ} \mathrm{E}$ & Do. \\
\hline CH-2006-1009 & 6.3 & South China Sea & $20.700^{\circ} \mathrm{N}$ & $120.104^{\circ} \mathrm{E}$ & Do. \\
\hline CH-2006-1226 & 7.0 & South China Sea & $21.823^{\circ} \mathrm{N}$ & $120.609^{\circ} \mathrm{E}$ & Do. \\
\hline CH-2007-0420 & 6.3 & East China Sea & $25.624^{\circ} \mathrm{N}$ & $125.260^{\circ} \mathrm{E}$ & Do. \\
\hline \multicolumn{6}{|c|}{ Europe (Storchak and others, 2012) } \\
\hline EU-1967-1018 & 5.6 & West of Svalbard & $79.765^{\circ} \mathrm{N}$ & $2.851^{\circ} \mathrm{E}$ & Oceanic crust \\
\hline EU-1992-0720 & 6.7 & West of Svalbard & $78.612^{\circ} \mathrm{N}$ & $5.503^{\circ} \mathrm{E}$ & Do. \\
\hline EU-1998-0321 & 6.2 & West of Svalbard & $79.833^{\circ} \mathrm{N}$ & $2.435^{\circ} \mathrm{E}$ & Do. \\
\hline EU-2005-0402 & 6.1 & West of Svalbard & $78.563^{\circ} \mathrm{N}$ & $6.156^{\circ} \mathrm{E}$ & Do. \\
\hline \multicolumn{6}{|c|}{ India (Ambraseys and Douglas, 2004) } \\
\hline IN-1803-0901 & 7.5 & Himalaya & $31.5^{\circ} \mathrm{N}$ & $79^{\circ} \mathrm{E}$ & $\begin{array}{l}\text { New and } \\
\text { reinterpreted } \\
\text { intensity } \\
\text { reports }\end{array}$ \\
\hline \multicolumn{6}{|c|}{ Indochina (Wheeler, 2011)2, 3} \\
\hline IO-1935-1101 & 6.6 & Northern Laos & $21.179^{\circ} \mathrm{N}$ & $103.119^{\circ} \mathrm{E}$ & Active rifting \\
\hline \multicolumn{6}{|c|}{ Mongolia (Wheeler, 2011) ${ }^{2,3}$} \\
\hline MO-1933-0323 & 5.9 & Central Mongolia & $48^{\circ} \mathrm{N}$ & $104^{\circ} \mathrm{E}$ & Do. \\
\hline
\end{tabular}

\footnotetext{
${ }^{1} \mathrm{M}_{\mathrm{W}}$ of both African earthquakes comes from instrumental $\mathrm{M}_{\mathrm{S}}$ (Ambraseys and Adams, 1991), converted to $\mathrm{M}_{\mathrm{W}}$ with table 1 of Johnston (1996a).

${ }^{2}$ Magnitudes are from Johnston and others (1994), Abe (1981), the Centennial catalog of Engdahl and Villasenor (2002) as updated and revised by A. Villasenor and colleagues (written communs., February 28, 2008 to September 9, 2009), and the online Global Centroid Moment-Tensor catalog (accessed on February 7, 2014 at http://www.globalcmt.org). Intensity data and instrumental $M_{S}$ values are converted to $M_{W}$ with the methods of Johnston (1996a, b).

${ }^{3}$ Latitudes and longitudes from the GEM catalog (Storchak and others, 2012), Johnston and others (1994), and Gutenberg and Richter (1954).
} 
Table 4. Events not verified as earthquakes.

[Catalogs listed in the last two columns are those covering the date of the earthquake (see table 1 for definitions of these catalog identifiers). These events are not listed in tables 6 or 8.]

\begin{tabular}{|c|c|c|c|c|c|c|}
\hline Event & Locale & Latitude & Longitude & Magnitude & $\begin{array}{l}\text { Listing } \\
\text { catalogs }\end{array}$ & Nonlisting catalogs \\
\hline $\begin{array}{l}\text { May } 26 \\
1618^{1}\end{array}$ & Western India & $18.9^{\circ} \mathrm{N}$ & $72.9^{\circ} \mathrm{E}$ & $\mathrm{M}_{\mathrm{W}} 7.0$ & $\begin{array}{l}\text { J94, SM05, } \\
\text { TS97 }\end{array}$ & None $^{2}$ \\
\hline $\begin{array}{l}\text { Sept. 16, } \\
1973\end{array}$ & $\begin{array}{l}\text { Eastern } \\
\text { Europe }\end{array}$ & $43.39^{\circ} \mathrm{N}$ & $57.33^{\circ} \mathrm{E}$ & $\mathrm{M}_{\mathrm{S}} 7.3$ & TS97 & $\begin{array}{l}\text { J94, C08, SM05, PDE, ISC, } \\
\text { GEM }\end{array}$ \\
\hline $\begin{array}{l}\text { Aug. 26, } \\
2001\end{array}$ & Greenland & $76.334^{\circ} \mathrm{N}$ & $20.322^{\circ} \mathrm{E}$ & $\mathrm{M}_{\mathrm{W}} 6.1$ & SM05 & $\begin{array}{l}\text { C08, PDE, ISC, CMT, } \\
\text { GEM }^{3}\end{array}$ \\
\hline Oct. 3, 2001 & New Guinea & $6.967^{\circ} \mathrm{S}$ & $137.052^{\circ} \mathrm{E}$ & $\mathrm{M}_{\mathrm{W}} 6.2$ & SM05 & $\begin{array}{l}\text { C08, PDE, ISC, CMT, } \\
\text { GEM }^{3}\end{array}$ \\
\hline $\begin{array}{l}\text { Nov. 14, } \\
2001\end{array}$ & $\begin{array}{l}\text { South China } \\
\text { Sea }\end{array}$ & $7.814^{\circ} \mathrm{N}$ & $105.944^{\circ} \mathrm{E}$ & $\mathrm{M}_{\mathrm{W}} 6.5$ & SM05 & $\begin{array}{l}\text { C08, PDE, ISC, CMT, } \\
\text { GEM }^{3}\end{array}$ \\
\hline
\end{tabular}

${ }^{1}$ The suggested Indian earthquake struck Mumbai during a hurricane (Metzger and Johnston, 1994). In unpublished notes, A.C. Johnston concluded that the event lacked enough supporting evidence to conclude that it was an earthquake (written commun., 2010). Schulte and Mooney (2005) and Triep and Sykes (1997) took their catalog entries for the event from Johnston and others (1994).

${ }^{2} \mathrm{C} 08$, ISC, PDE, and GEM not listed because event occurred before their oldest earthquakes.

${ }^{3}$ TS97 not listed because event occurred after its compilation. 
Table 5. Preference hierarchy for choice of the best value from among those in two or more earthquake catalogs.

[See table 1 for catalog identifiers. SCR, stable continental region]

\begin{tabular}{|c|c|}
\hline Earthquake Property & Catalogs listed in decreasing order of preference (see text for explanations) \\
\hline $\begin{array}{l}\text { Origin time and } \\
\text { epicenter }\end{array}$ & $\begin{array}{l}\text { (1) GEM, (2) C08, (3) ISC, (4) values from other sources that C08 lists as preferred, } \\
\text { (5) values from other sources that J94 lists as preferred, (6) values listed in other } \\
\text { catalogs of table } 1\end{array}$ \\
\hline Scalar moment & $\begin{array}{l}\text { (1) CMT, (2) Johnston (1996a), (3) moments quoted from the literature by Johnston } \\
\text { and others (1994) }\end{array}$ \\
\hline Converted magnitudes & $\begin{array}{l}\text { (1) } \mathrm{M}_{\mathrm{S}} \text { listed as preferred in C08, (2) } \mathrm{M}_{\mathrm{S}} \text { from ISC if ISC is author, (3) conversions } \\
\text { from other magnitude types, intensities, or other information given in C08, J94, } \\
\text { Abe }(1981,1984 \text { ) or Abe and Noguchi }(1983 \mathrm{a}, \mathrm{b}) \text {, or isoseismal areas that A.C. } \\
\text { Johnston remeasured from others' published isoseismal maps and listed in his } \\
\text { unpublished magnitude-calculation sheets (oral and written communs., October } \\
\text { 2009-March 2011), (4) } \mathrm{M}_{\mathrm{W}} \text { from GEM, calculated by conversion from } \mathrm{M}_{\mathrm{S}} \text { or } \mathrm{m}_{\mathrm{b}}\end{array}$ \\
\hline $\begin{array}{l}\text { Distance from SCR } \\
\text { boundary }\end{array}$ & $\begin{array}{l}\text { All distances were measured with the ESRI }{ }^{\circledR} \text { ArcMap }^{\mathrm{TM}} 9.3 \text { software on scans of the } \\
\text { maps of Broadbent and Allan Cartography (1994) }\end{array}$ \\
\hline Depth & (1) GEM, (2) C08, (3) J94, (4) PDE, (5) SM05, (6) TS97, (7) GR54 \\
\hline
\end{tabular}


Table 6. Earthquakes having two or more size estimates that were combined with the method of Johnston (1996b).

[See table 2 for explanation of earthquake identifiers in column one. For each earthquake, the moment magnitude $\mathrm{M}_{\mathrm{W}}$ and its standard deviation $\sigma$ are calculated for each listed kind of data. $\mathrm{M}(\mathrm{comb})$ and $\sigma(\mathrm{comb})$ are the combined values (see text). Leaders (-), no value for $\mathrm{M}(\mathrm{comb})$ or $\sigma(\mathrm{comb})$ because each of these variables has only one value of $\mathrm{M}$ and one of $\sigma$ per earthquake; -------do-------, ditto. This table excludes foreshocks and aftershocks (table 2), earthquakes now known to have occurred in active continental crust (table 3 ), and events not verified as earthquakes (table 4). Table 7 lists excluded $\mathrm{M}_{\mathrm{W}}$ estimates for earthquakes listed below, with justifications of the exclusions.

Abbreviations: Af, felt area; Aiii, area enclosed by the Modified Mercalli Intensity III isoseismal, and similarly for other intensity levels; All A, combined estimates of $\mathrm{M}_{\mathrm{W}}$ and its standard deviation, calculated from the preceding two or more of Af, Aiii, and so forth, with correction for systematic uncertainties in isoseismals (see text); CII, Community Internet Intensity; Imax, the highest intensity level reported for a specified earthquake; Jwc, see next paragraph; $\mathrm{m}_{\mathrm{b}}$, teleseismic bodywave magnitude; Mi, magnitude inferred from intensities and equated to an instrumental magnitude; $\mathrm{M}_{\mathrm{S}}$, surface-wave magnitude. Johnston (1994, p. 3-18) assigned Mi an uncertainty of 0.5 and this report follows that practice; MMI, Modified Mercalli Intensity.

Jwc: unpublished magnitude-calculation worksheets of A.C. Johnston (oral and written communs., October 2009 to March 2011). Metzger and Johnston (1994) published data sheets for each earthquake that Johnston and others (1994) had compiled. Many of the data sheets show isoseismal maps and isoseismal areas that Metzger and Johnston compiled from cited sources. However, Johnston and others (1994) remeasured all isoseismal areas and used the unpublished results to calculate $\mathrm{M}_{\mathrm{W}}$ and $\sigma$ (Johnston, 1994, p. 3-38). This table uses the remeasured values.]

\begin{tabular}{|c|c|c|c|c|c|c|}
\hline $\begin{array}{c}\text { Earthquake } \\
\text { identifier }\end{array}$ & Data & Source & $M_{w}$ & $\sigma$ & $M($ comb $)$ & $\sigma(\mathrm{comb})$ \\
\hline \multicolumn{7}{|c|}{ Africa } \\
\hline \multirow{2}{*}{ AF-1636-1218 } & $\operatorname{Imax}$ & -------do-------- & 6.4 & 0.53 & - & - \\
\hline & Mi & -------do-------- & 5.8 & 0.50 & 6.1 & 0.31 \\
\hline \multirow[t]{2}{*}{ AF-1820-0000 } & Avi & -------do------- & 6.3 & 0.60 & - & - \\
\hline & Mi & -------do------- & 6.2 & 0.50 & 6.2 & 0.38 \\
\hline AF-1850-0100 & $\operatorname{Imax}$ & -------do------- & 6.4 & 0.53 & - & - \\
\hline \multirow[t]{5}{*}{$\mathrm{AF}-1862-0710^{2}$} & Avi & -------do------- & 6.7 & 0.42 & - & - \\
\hline & Aiii & -------do------- & 5.8 & 0.39 & - & - \\
\hline & All A & Johnston (1996b) & 6.2 & 0.41 & - & - \\
\hline & Mi & Metzger and Johnston (1994) & 6.5 & 0.50 & - & - \\
\hline & $\operatorname{Imax}$ & --------do-------- & 6.7 & 0.54 & 6.4 & 0.27 \\
\hline \multirow[t]{2}{*}{ AF-1908-0402 } & $\operatorname{Imax}$ & -------do------- & 4.2 & 0.52 & - & - \\
\hline & Aiii & -------do-------- & 5.7 & 0.56 & - & - \\
\hline
\end{tabular}


Table 6. Earthquakes having two or more size estimates that were combined with the method of Johnston (1996b).-Continued

\begin{tabular}{|c|c|c|c|c|c|c|}
\hline $\begin{array}{c}\text { Earthquake } \\
\text { identifier }\end{array}$ & Data & Source & $M_{w}$ & $\sigma$ & $M(c o m b)$ & $\sigma(\mathrm{comb})$ \\
\hline & $\mathrm{m}_{\mathrm{b}}$ & -------do------- & 6.4 & 0.27 & - & - \\
\hline & $\mathrm{M}_{\mathrm{S}}$ & -------do------- & 6.1 & 0.18 & 6.0 & 0.14 \\
\hline \multirow[t]{5}{*}{ AF-1912-0220 } & Av & Jwc & 5.4 & 0.36 & - & - \\
\hline & Avi & Jwc & 5.0 & 0.36 & - & - \\
\hline & Avii & Jwc & 4.3 & 0.37 & - & - \\
\hline & All A & Johnston (1996b) & 4.9 & 0.30 & - & - \\
\hline & $\mathrm{M}_{\mathrm{S}}$ & Metzger and Johnston (1994) & 5.9 & 0.18 & 5.6 & 0.16 \\
\hline \multirow[t]{6}{*}{ AF-1915-0521 } & Aiii & Jwc & 5.6 & 0.27 & - & - \\
\hline & $\mathrm{Av}$ & Jwc & 5.5 & 0.46 & - & - \\
\hline & All A & Johnston (1996b) & 5.6 & 0.33 & - & - \\
\hline & Imax & Metzger and Johnston (1994) & 5.8 & 0.52 & - & - \\
\hline & $\mathrm{m}_{\mathrm{b}}$ & -------do------- & 6.9 & 0.30 & - & - \\
\hline & $\mathrm{M}_{\mathrm{S}}$ & -------do------- & 6.3 & 0.18 & 6.3 & 0.14 \\
\hline \multirow[t]{2}{*}{ AF-1919-1031 } & $\operatorname{Imax}$ & -------do------- & 5.8 & 0.52 & - & - \\
\hline & $\mathrm{M}_{\mathrm{S}}$ & -------do------- & 6.3 & 0.18 & 6.2 & 0.17 \\
\hline \multirow[t]{7}{*}{ AF-1932-1231 } & Aiii & -------do------- & 6.0 & 0.27 & - & - \\
\hline & Aiv & -------do------- & 6.0 & 0.36 & - & - \\
\hline & $\mathrm{Av}$ & -------do------- & 6.1 & 0.46 & - & - \\
\hline & Avi & -------do------- & 6.5 & 0.42 & - & - \\
\hline & Avii & -------do------- & 6.8 & 0.44 & - & - \\
\hline & All A & Johnston (1996b) & 6.2 & 0.23 & - & - \\
\hline & $\mathrm{M}_{\mathrm{S}}$ & Metzger and Johnston (1994) & 6.6 & 0.19 & 6.4 & 0.15 \\
\hline \multicolumn{7}{|c|}{ Arabia } \\
\hline \multirow[t]{2}{*}{ AR-1068-0318 } & Aiii-iv & Metzger and Johnston (1994), Jwc & 6.9 & 0.71 & - & - \\
\hline & Mi & Metzger and Johnston (1994) & 7.0 & 0.50 & 6.9 & 0.41 \\
\hline \multirow[t]{2}{*}{ AR-1130-0227 } & Aiv & -------do------- & 6.0 & 0.51 & - & - \\
\hline & $\mathrm{Mi}$ & -------do------- & 6.8 & 0.50 & 6.4 & 0.36 \\
\hline
\end{tabular}


Table 6. Earthquakes having two or more size estimates that were combined with the method of Johnston (1996b).-Continued

\begin{tabular}{|c|c|c|c|c|c|c|}
\hline $\begin{array}{c}\text { Earthquake } \\
\text { identifier }\end{array}$ & Data & Source & $M_{w}$ & $\sigma$ & $M(c o m b)$ & $\sigma(\mathrm{comb})$ \\
\hline \multirow[t]{2}{*}{ AR-1179-0429 } & Aiv & -------do------- & 5.7 & 0.51 & - & - \\
\hline & $\mathrm{Mi}$ & -------do------- & 6.6 & 0.50 & 6.2 & 0.36 \\
\hline \multirow[t]{3}{*}{ AR-1917-0715 } & Aiv & -------do------- & 5.9 & 0.51 & - & - \\
\hline & $\mathrm{m}_{\mathrm{b}}$ & -------do------- & 6.4 & 0.27 & - & - \\
\hline & $\mathrm{M}_{\mathrm{S}}$ & -------do-------- & 5.7 & 0.18 & 5.9 & 0.15 \\
\hline \multicolumn{7}{|c|}{ Australia } \\
\hline \multirow[t]{4}{*}{ AU-1885-0512 } & Aiii & Jwc & 5.7 & 0.27 & & \\
\hline & Aiv & Jwc & 5.5 & 0.36 & - & - \\
\hline & Av & Jwc & 6.1 & 0.46 & - & - \\
\hline & Avi & Jwc & 6.4 & 0.42 & 5.8 & 0.25 \\
\hline \multirow[t]{3}{*}{ AU-1892-0126 } & Aiv & Jwc & 6.0 & 0.36 & - & - \\
\hline & Av & Jwc & 6.4 & 0.46 & - & - \\
\hline & Avi & Jwc & 6.4 & 0.42 & 6.2 & 0.33 \\
\hline \multirow[t]{4}{*}{ AU-1897-0510 } & Aiii & Jwc & 6.0 & 0.27 & - & - \\
\hline & Aiv & Jwc & 5.8 & 0.36 & - & - \\
\hline & Av & Jwc & 6.0 & 0.46 & - & - \\
\hline & Avi & Jwc & 6.6 & 0.42 & 6.0 & 0.25 \\
\hline \multicolumn{7}{|c|}{ China } \\
\hline \multirow[t]{4}{*}{ CH-1631-0814 } & $\mathrm{Av}$ & Jwc & 6.7 & 0.47 & - & - \\
\hline & Avii & Jwc & 6.5 & 0.43 & - & - \\
\hline & All A & Johnston (1996b) & 6.6 & 0.45 & - & - \\
\hline & $\mathrm{Mi}$ & Metzger and Johnston (1994) & 6.5 & 0.50 & 6.5 & 0.33 \\
\hline \multirow[t]{5}{*}{ CH-1936-0401 } & Av & Jwc & 5.8 & 0.46 & - & - \\
\hline & Avi & Jwc & 6.0 & 0.42 & - & - \\
\hline & All A & Johnston (1996b) & 5.9 & 0.44 & - & - \\
\hline & $\mathrm{m}_{\mathrm{b}}$ & Metzger and Johnston (1994) & 5.7 & 0.26 & - & - \\
\hline & $\mathrm{M}_{\mathrm{S}}$ & -------do------- & 6.8 & 0.19 & 6.3 & 0.15 \\
\hline
\end{tabular}


Table 6. Earthquakes having two or more size estimates that were combined with the method of Johnston (1996b).-Continued

\begin{tabular}{|c|c|c|c|c|c|c|}
\hline $\begin{array}{l}\text { Earthquake } \\
\text { identifier }\end{array}$ & Data & Source & Mw & $\sigma$ & $M(c o m b)$ & $\sigma(\mathrm{comb})$ \\
\hline \multicolumn{7}{|c|}{ Eurasia } \\
\hline \multirow[t]{3}{*}{ EU-1580-0406 } & Av & Metzger and Johnston (1994), Jwc & 6.7 & 0.47 & - & - \\
\hline & Avi & Metzger and Johnston (1994), Jwc & 7.0 & 0.42 & - & - \\
\hline & Avii & Metzger and Johnston (1994), Jwc & 7.0 & 0.44 & 6.9 & 0.36 \\
\hline \multirow[t]{4}{*}{ EU-1819-0831 } & Aiii & Jwc & 6.6 & 0.27 & - & - \\
\hline & Aiv & Jwc & 6.4 & 0.36 & - & - \\
\hline & $\mathrm{Av}$ & Jwc & 6.3 & 0.46 & - & - \\
\hline & Avi & Jwc & 6.3 & 0.42 & 6.5 & 0.25 \\
\hline \multirow[t]{3}{*}{ EU-1827-0500 } & Avii & Metzger and Johnston (1994) & 6.4 & 0.61 & - & - \\
\hline & $\operatorname{Imax}$ & -------do------- & 5.8 & 0.52 & - & - \\
\hline & $\mathrm{Mi}$ & -------do------- & 6.5 & 0.50 & 6.2 & 0.31 \\
\hline \multirow[t]{2}{*}{ EU-1895-0808 } & Aviii & -------do------- & 6.8 & 0.50 & - & - \\
\hline & $\operatorname{Imax}$ & -------do------- & 5.8 & 0.52 & 6.3 & 0.36 \\
\hline \multicolumn{7}{|c|}{ Iberia } \\
\hline \multirow[t]{3}{*}{ IB-1858-1111 } & Av & Jwc & 6.2 & 0.46 & - & - \\
\hline & Avi & Jwc & 6.8 & 0.42 & - & - \\
\hline & Avii & Jwc & 7.0 & 0.44 & 6.7 & 0.36 \\
\hline \multirow[t]{2}{*}{ IB-1903-0809 } & Av & Jwc & 6.3 & 0.46 & - & - \\
\hline & Avi & Jwc & 6.4 & 0.42 & 6.4 & 0.44 \\
\hline \multicolumn{7}{|c|}{ India } \\
\hline \multirow[t]{4}{*}{ IN-1819-0616 } & New intensities, kriging & Ambraseys and Douglas (2004) & 8.5 & 0.46 & - & - \\
\hline & Liquefaction distance & $\begin{array}{l}\text { Rajendran and Rajendran (2001), Tuttle } \\
\text { (2012) }\end{array}$ & 7.7 & 0.50 & - & - \\
\hline & Scarp length & $\begin{array}{l}\text { Rajendran and Rajendran (2001), } \\
\text { Leonard (2010) }\end{array}$ & 7.6 & 0.14 & - & - \\
\hline & Geometric model & $\begin{array}{l}\text { Bilham and others (2003), Bilham } \\
\text { (1998) }\end{array}$ & 7.7 & 0.20 & 7.7 & 0.11 \\
\hline \multirow[t]{2}{*}{ IN-1927-0602 } & Af & Metzger and Johnston (1994) & 4.9 & 0.56 & - & - \\
\hline & $\mathrm{M}_{\mathrm{S}}$ & -------do------- & 6.3 & 0.18 & 6.1 & 0.25 \\
\hline
\end{tabular}


Table 6. Earthquakes having two or more size estimates that were combined with the method of Johnston (1996b).-Continued

\begin{tabular}{|c|c|c|c|c|c|c|}
\hline $\begin{array}{l}\text { Earthquake } \\
\text { identifier }\end{array}$ & Data & Source & $M_{w}$ & $\sigma$ & $M(c o m b)$ & $\sigma(\mathrm{comb})$ \\
\hline \multicolumn{7}{|c|}{ North America } \\
\hline \multirow[t]{4}{*}{ NA-1663-0205 } & Af & -------do------- & 5.9 & 0.56 & - & - \\
\hline & $\begin{array}{l}\text { MMI of } 1663 \text { vs. } 1925 \\
\text { shocks }\end{array}$ & Basham and others $(1979,1982)$ & 6.2 & 0.50 & - & - \\
\hline & $\begin{array}{l}\text { Felt distances of } \\
\text { aftershocks }\end{array}$ & Ebel (1996) & 7.4 & 0.50 & - & - \\
\hline & $\begin{array}{l}\text { Attenuation, fragility, } \\
\text { soils }\end{array}$ & Ebel (2011) & 7.5 & 0.45 & 6.8 & 0.25 \\
\hline \multirow[t]{6}{*}{ NA-1732-0916 } & Af & Metzger and Johnston (1994) & 6.0 & 0.39 & - & - \\
\hline & Aiv & -------do------- & 6.2 & 0.36 & - & - \\
\hline & $\mathrm{Av}$ & -------do------- & 6.0 & 0.46 & - & - \\
\hline & Avi & -------do------- & 6.3 & 0.42 & - & - \\
\hline & All A & Johnston (1996b) & 6.1 & 0.29 & - & - \\
\hline & $\operatorname{Imax}$ & Metzger and Johnston (1994) & 5.8 & 0.54 & 6.1 & 0.25 \\
\hline \multirow[t]{7}{*}{ NA-1755-1118 } & Af & Metzger and Johnston (1994), Jwc & 5.4 & 0.39 & - & - \\
\hline & Aiv & -------do------- & 6.4 & 0.36 & - & - \\
\hline & $\mathrm{Av}$ & -------do------- & 6.4 & 0.46 & - & - \\
\hline & Avi & -------do------- & 6.2 & 0.42 & - & - \\
\hline & All A & Johnston (1996b) & 6.1 & 0.29 & - & - \\
\hline & $\begin{array}{l}\text { Isoseismal-free } \\
\text { computation }\end{array}$ & $\begin{array}{l}\text { Bakun and others (2003), Bakun and } \\
\text { Hopper (2004) }\end{array}$ & 6.3 & 0.25 & - & - \\
\hline & MMI attenuation & Ebel (2006) & 5.9 & 0.15 & 6.0 & 0.12 \\
\hline \multirow[t]{7}{*}{ NA-1812-0207 } & Aiv-Avii & Johnston (1996c) & 8.0 & 0.33 & - & - \\
\hline & Revised MMI values & Hough and others (2000) & 7.4 & 0.30 & - & - \\
\hline & Liquefaction distribution & $\begin{array}{l}\text { Tuttle and others (2002a,b), Tuttle } \\
\text { (2012) }\end{array}$ & 7.6 & 0.50 & - & - \\
\hline & $\begin{array}{l}\text { Isoseismal-free } \\
\text { computation }\end{array}$ & Bakun and Hopper (2004) & 7.8 & 0.28 & - & - \\
\hline & Four MMI analysts & Hough and Page (2011) & 7.2 & 0.38 & - & - \\
\hline & $\begin{array}{l}\text { CII-MMI differences, } \\
\text { population } \\
\text { distributions }\end{array}$ & Boyd and Cramer (2014) & 7.4 & 0.40 & - & - \\
\hline & $\begin{array}{l}\text { Attenuation of distant } \\
\text { MMI }\end{array}$ & Cramer and Boyd (in press) & 7.7 & 0.15 & 7.7 & 0.10 \\
\hline NA-1843-0105 & Aiii-Aviii & Johnston (1996c) & 6.3 & 0.29 & - & - \\
\hline
\end{tabular}


Table 6. Earthquakes having two or more size estimates that were combined with the method of Johnston (1996b).-Continued

\begin{tabular}{|c|c|c|c|c|c|c|}
\hline $\begin{array}{l}\text { Earthquake } \\
\text { identifier }\end{array}$ & Data & Source & $\mathrm{Mw}_{\mathrm{w}}$ & $\sigma$ & $M(c o m b)$ & $\sigma(\mathrm{comb})$ \\
\hline & $\begin{array}{l}\text { Isoseismal-free } \\
\text { computation }\end{array}$ & Bakun and others (2003) & 6.2 & 0.18 & 6.2 & 0.15 \\
\hline \multirow[t]{3}{*}{ NA-1870-1020 } & Af & Metzger and Johnston (1994) & 6.3 & 0.56 & - & - \\
\hline & $\operatorname{Imax}$ & -------do------- & 5.8 & 0.52 & - & - \\
\hline & $\begin{array}{l}\text { Isoseismal-free } \\
\text { computation }\end{array}$ & Ebel and others (2013) & 5.8 & 0.12 & 5.8 & 0.12 \\
\hline \multirow[t]{4}{*}{ NA-1886-0901 } & Af-Aviii & Johnston (1996c) & 7.3 & 0.26 & - & - \\
\hline & $\begin{array}{l}\text { Isoseismal-free } \\
\text { computation }\end{array}$ & Bakun and Hopper (2004) & 6.9 & 0.15 & - & - \\
\hline & $\begin{array}{l}\text { CII-MMI differences, } \\
\text { population } \\
\text { distributions }\end{array}$ & Boyd and Cramer (2014) & 6.9 & 0.30 & - & - \\
\hline & $\begin{array}{l}\text { Attenuation of distant } \\
\text { MMI. }\end{array}$ & Cramer and Boyd (in press) & 7.0 & 0.15 & 7.0 & 0.09 \\
\hline \multirow[t]{2}{*}{ NA-1895-1031 } & Af-Aviii & Johnston (1996c) & 6.6 & 0.29 & - & - \\
\hline & $\begin{array}{l}\text { Isoseismal-free } \\
\text { computation }\end{array}$ & Bakun and others (2003) & 6.2 & 0.15 & 6.3 & 0.13 \\
\hline \multirow[t]{7}{*}{ NA-1935-1019 } & Af & Jwc & 5.1 & 0.39 & - & - \\
\hline & Aiv & Jwc & 5.6 & 0.36 & - & - \\
\hline & Av & Jwc & 5.7 & 0.46 & - & - \\
\hline & Avi & Jwc & 5.3 & 0.42 & - & - \\
\hline & All A & Johnston (1996b) & 5.4 & 0.29 & - & - \\
\hline & $\operatorname{Imax}$ & Metzger and Johnston (1994) & 5.8 & 0.52 & - & - \\
\hline & $\mathrm{M}_{\mathrm{S}}$ & -------do-------- & 6.0 & 0.18 & 5.8 & 0.15 \\
\hline \multicolumn{7}{|c|}{ South America } \\
\hline \multirow[t]{6}{*}{ SA-1939-0628 } & Af & Jwc & 5.6 & 0.39 & - & - \\
\hline & Aiv & Jwc & 6.0 & 0.36 & - & - \\
\hline & Av & Jwc & 6.0 & 0.46 & - & - \\
\hline & Avi & Jwc & 6.4 & 0.42 & - & - \\
\hline & All A & Johnston (1996b) & 6.0 & 0.29 & - & - \\
\hline & $\mathrm{M}_{\mathrm{S}}$ & Metzger and Johnston (1994) & 5.6 & 0.18 & 5.7 & 0.15 \\
\hline \multirow[t]{2}{*}{ SA-1955-0131 } & $\mathrm{m}_{\mathrm{b}}$ & -------do------- & 6.3 & 0.27 & - & - \\
\hline & $\mathrm{M}_{\mathrm{S}}$ & -------do------- & 5.6 & 0.18 & 5.8 & 0.15 \\
\hline
\end{tabular}

${ }^{1}$ Earthquake AF-1636-1218: Isoseismal $\mathrm{M}_{\mathrm{W}}$ estimates are inherently more subjective than most other $\mathrm{M}_{\mathrm{W}}$ estimates (Johnston 1996b, p. 648, equation 18). Johnston (1996b) recommends that any $\sigma$ that was estimated from isoseismal areas 
should be increased according to his equation 18. In this example, there is a single isoseismal area and the result is to increase $\sigma$ for Avii from 0.43 to 0.60 . See also footnote 2 for an example with two or more isoseismals.

${ }^{2}$ Earthquake AF-1862-0710: If $\mathrm{M}_{\mathrm{W}}$ estimates and their standard deviations are calculated from two or more isoseismal areas and then combined, $\sigma(\mathrm{comb})$ of the combination is increased according to equation 18 of Johnston (1996b, p. 648) to account for systematic uncertainties in isoseismals. The result is listed here as "All A." The effect is to increase $\sigma(\mathrm{comb})$ for the combination of Avi and Aiii from 0.29 to 0.41 .

${ }^{3}$ Earthquake AR-1068-0318: Metzger and Johnston (1994) quote sparse intensity reports for this earthquake. Jwc interprets the reports as indicating either Aiii or Aiv, which would predict $M_{W} 6.6$ or $M_{W} 7.2$, respectively. This report uses the average $\mathrm{M}_{\mathrm{W}}$ of 6.9. Johnston (1994, p. 3-18) and assigns $\sigma=0.50$ to "magnitude estimated from quoted isoseismal areas or radii." Additionally, because $\mathrm{M}_{\mathrm{W}} 6.9$ is from an isoseismal, its standard deviation should be increased (see footnote 1). Here, the result is to increase $\sigma$ from 0.50 to 0.71 .

${ }^{4}$ Earthquake EU-1580-0406: Metzger and Johnston (1994) show two intensity maps for this earthquake, one by Melville and one by Nielson. Metzger and Johnston list isoseismal areas from Melville's map. However, Jwc used Nielson's map because it corrects some errors in the map of Melville. This report follows the preference of Jwc.

${ }^{5}$ Earthquake IN-1819-0616: Rajendran and Rajendran (2001) report that the most distant observed liquefaction caused by this earthquake occurred about 250 kilometers away. Rajendran and Rajendran use an empirical relation by Ambraseys (1988) to estimate $\mathrm{M}_{\mathrm{W}}$. Tuttle (2012) discusses uncertainties in such $\mathrm{M}_{\mathrm{W}}$ estimates and suggests that $\sigma$ may be 0.50 . 


\section{Table 7. Mw estimates not used.}

[See table 2 for explanation of earthquake identifiers in column one. Each earthquake listed below has had $\mathrm{M}_{\mathrm{W}}$ estimated in two or more publications. This table explains why some of the estimates are not among those that were combined to give estimates of the combined magnitude $\mathrm{M}_{\mathrm{W}}(\mathrm{comb})$ and its standard deviation $\sigma(\mathrm{comb})$ (see table 6 for definitions of these two symbols). -Do.-, ditto]

\begin{tabular}{|c|c|c|c|}
\hline Earthquake identifier & Reference estimating MW & Method used & Reason for exclusion of MW estimate \\
\hline \multirow[t]{2}{*}{$\begin{array}{l}\text { IN-1819-0616 } \\
\text { (Kutch, India) }\end{array}$} & $\begin{array}{l}\text { Quittmeyer and Jacobs } \\
\text { (1979) }\end{array}$ & Geometric modeling & $\begin{array}{l}\text { Slip estimate is vertical offset, not } \\
\text { fault-parallel slip }\end{array}$ \\
\hline & $\begin{array}{l}\text { Rajendran and Rajendran } \\
\text { (2001) }\end{array}$ & Geometric modeling & -Do.- \\
\hline \multirow{8}{*}{$\begin{array}{l}\text { NA-1812-0207 (New } \\
\text { Madrid seismic } \\
\text { zone, Tennessee; } \\
\text { Reelfoot scarp) }\end{array}$} & Nuttli (1973a) & $\mathrm{m}_{\mathrm{b}}$ & $\begin{array}{l}\mathrm{m}_{\mathrm{b}} \text { is likely saturated (Johnston, } \\
\text { 1996a); no } \sigma \text { included }\end{array}$ \\
\hline & Nuttli (1983) & Spectral scaling & No $\sigma$ included \\
\hline & Gomberg (1993) & $\begin{array}{l}\text { Boundary-element } \\
\text { modeling }\end{array}$ & -Do.- \\
\hline & Mueller and Pujol (2001) & $\begin{array}{l}\text { Structural modeling of } \\
\text { the Reelfoot fault }\end{array}$ & -Do.- \\
\hline & Tuttle (2001) & Liquefaction features & $\begin{array}{l}\text { Published } \sigma \text { is too small (Tuttle, } \\
\text { 2012) }\end{array}$ \\
\hline & Hough and others (2002) & $\begin{array}{l}\text { Compare map } \\
\text { distributions of } \\
\text { intensities to those of } \\
\text { IN-2001-0126 }\end{array}$ & No $\sigma$ included \\
\hline & $\begin{array}{l}\text { Tuttle and others } \\
(2002 a, b)\end{array}$ & $\begin{array}{l}\text { Sizes and map } \\
\text { distributions of } \\
\text { liquefaction features }\end{array}$ & -Do.- \\
\hline & $\begin{array}{l}\text { Holzer and others ( } 2010, \\
2011)\end{array}$ & $\begin{array}{l}\text { Geotechnical data and } \\
\text { analyses }\end{array}$ & -Do.- \\
\hline $\begin{array}{l}\text { NA-1843-0105 } \\
\text { (Marked Tree, } \\
\text { Arkansas) }\end{array}$ & Nuttli (1974) & Intensity attenuation & -Do.- \\
\hline \multirow{4}{*}{$\begin{array}{l}\text { NA-1886-0901 } \\
\text { (Charleston, South } \\
\text { Carolina) }\end{array}$} & Bollinger (1977) & Intensity attenuation & -Do.- \\
\hline & Nuttli (1983) & $\begin{array}{l}\text { Maximum intensity, } \\
\text { isoseismal maps }\end{array}$ & -Do.- \\
\hline & Campbell (1986) & -Do.- & -Do.- \\
\hline & $\begin{array}{l}\text { Heidari and Andrus } \\
\text { (2010) }\end{array}$ & Liquefaction potential & -Do.- \\
\hline $\begin{array}{l}\text { NA-1895-1031 } \\
\text { (Charleston, } \\
\text { Missouri) }\end{array}$ & Nuttli (1974) & Intensity attenuation & -Do.- \\
\hline
\end{tabular}




\section{Table 8. Global Catalog of Historical Earthquakes for Estimation of Mmax in Central and Eastern United States}

[Column headings: Identifier, see definitions in table 2; Catalog, the earthquake catalog in which the earthquake's record was found (see table 1 for acronym definitions); Year, Month, Day, Hour, Minute, Second, date and origin time of the earthquake; Source1, catalog source of the origin time (table 1); Latitude and Longitude, epicenter; Source2, catalog source of the epicenter (table 1); Original Data, the data from which moment magnitude $\mathrm{M}_{\mathrm{W}}$ was calculated (see next paragraph for abbreviations and acronyms); Source3, sources of the original data (see last paragraph for acronym definitions); $\mathrm{M}_{\mathrm{W}}$, moment magnitude; Source4, sources from which $\mathrm{M}_{\mathrm{W}}$ was taken or calculated (see last paragraph for acronym definitions); $\sigma$, standard deviation of $\mathrm{M}_{\mathrm{W}}$; Source5, source of $\sigma$ (see last paragraph for acronym definitions); Type, the kind of continental crust within which the earthquake occurred (ACR, active continental crust; SCR, stable continental crust; TI, transitional crust, that is, inside an SCR but 40 kilometers [km] or less from its boundary; TO, active continental or oceanic crust, but 40 $\mathrm{km}$ or less from the nearest SCR [Johnston, 1994]); Zone, the type of source zone throughout which Mmax is assumed to be uniform worldwide (CRAT, craton; EM, extended margin; HEM, highly extended outer part of EM; SCR, stable continental region [Johnston, 1994; Kanter, 1994; Wheeler and Frankel, 2000; Petersen and others, 2008; Wheeler, 2011]); Distance, kilometers between the epicenter and the nearest SCR boundary, positive for earthquakes within an SCR and negative otherwise.

Abbreviations and acronyms in Original Data fields: Af, felt area; Aiii, area enclosed by the Modified Mercalli Intensity III isoseismal, and similarly for other intensity levels; Bakun, the isoseismal-free method of Bakun and others (2003) and Bakun and Hopper (2004); CII, Community Internet Intensity; Dlf, distance to the farthest liquefaction feature known to have been caused by the earthquake; Imax, maximum intensity reported for the earthquake; km, kilometers; liq., field study of liquefaction features; $M$, moment magnitude from GEM catalog; $\mathrm{m}_{\mathrm{B}}$, body-wave magnitude; $\mathrm{m}_{\mathrm{b}}$, teleseismic body-wave magnitude; $\mathrm{M}_{\mathrm{L}}$, local magnitude; $\mathrm{Mi}$, magnitude inferred from intensities and equated to an instrumental magnitude; $\mathrm{M}_{0}$, seismic moment; $\mathrm{M}_{\mathrm{S}}$, surface-wave magnitude; Riii, radius of circle with area equal to Aiii, and similarly for other intensity levels; SRL, surface-rupture length.

Acronyms in Source fields: see table 1 for definitions of AB81, AN83a, AN83b, C08, CMT, GEM, GR54, ISC, ISS, J94, PDE, SM05; A94, Ambraseys and others (1994); ARBL, Ambraseys (1988), Ambraseys and Douglas (2004), Leonard (2010), Bilham (1998), Bilham and others (2003), Rajendran and Rajendran (2001); B03, Bakun and others (2003); B04, Bakun and Hopper (2004); B7982, Basham and others (1979; 1982); E06, Ebel (2006); E13, Ebel and others (2013); E9611, Ebel (1996, 2011); ECOS, Earthquake Catalog of Switzerland 2009, of the Swiss Seismological Service, accessed on February 7, 2014 at http://www.seismo.ethz.ch/index_EN; F09, Fah and others (2009); H00, Hough and others (2000); HP11, Hough and Page (2011); J96a, b, c, Johnston (1996a,b,c); L10, Leonard (2010); T12, Tuttle (2012).] 